\title{
Privatization and Economic and Social Rights
}

\author{
Aoife Nolan ${ }^{*}$ \\ To be cited as 'Privatization and Economic and Social Rights' (2018) 40(4) Human Rights
}

Quarterly (forthcoming November 2018

\begin{abstract}
Privatization is an ever more dominant model of economic and social rights (ESR) realization. Contracting out, public-private partnerships, and other approaches by which the private sector takes responsibility for, or supports the state in, delivering ESR-related goods and services are being advanced aggressively at both the national and supranational levels, with international financial institutions playing an especially influential role. Thus far, however, there has been relatively little attention paid to privatization in ESR scholarship and practice, resulting in a significant lacuna from both a normative and an empirical perspective. This gap is perhaps most striking - and worrying - in relation to the work of those international bodies mandated with interpreting and applying the ESR standards under international law. Taking as its starting point the delineation of ESR obligations in terms of the tripartite typology of respect, protect, and fulfill outlined by the United Nations Committee on Economic, Social and Cultural Rights, this article considers how that framework (and the human rights treaty-monitoring bodies which employ it in their work) addresses privatization from an ESR perspective. Highlighting an excessive emphasis on the obligation to protect to the exclusion of other relevant levels of obligation, the author asserts that such an approach is reflective of a failure to conceptualize privatization and the state's role with regard to such properly - a failure that has very serious implications for the ability of the ESR framework as it stands to capture rights-harming actions in the context of privatization effectively. Arguing for a shift to the obligation to fulfill, the author contends this alternative approach would contribute significantly to the ability of ESR law as it stands to capture - and address - the full scope of state decision-making and (in)action at issue in situations of privatization. The article concludes with observations on recent moves by the Committee which though in the right direction leave much work to be done.
\end{abstract}

\footnotetext{
* Thanks are due to Sylvain Aubry, Carlos Bernal-Pulido, Gráinne de Búrca, Rosalind Dixon, Conor Gearty, Beth Goldblatt, Sandy Liebenberg, Denise Myerson, Paul O’Connell, Theunis Roux, Bret Thiele, Nigel White and participants in the NYU Hauser Global Fellows Forum for very helpful comments on early iterations of this article and for discussions around the topic more generally. Petr Mádr provided excellent research assistance. Responsibility for any shortcomings or omissions that remain rests solely with the author.
} 


\section{INTRODUCTION}

Privatization is an ever more dominant model of economic and social rights (ESR) realization. Contracting out, public-private partnerships, and other approaches by which the private sector takes responsibility for, or supports the state in, delivering ESR-related goods and services are being advanced aggressively at both the national and supranational levels, with international financial institutions playing an especially influential role. Thus far, however, there has been relatively little attention paid to privatization in ESR scholarship and practice, resulting in a significant lacuna from both a normative and an empirical perspective. This gap is perhaps most striking-and worrying-in relation to the work of those international bodies that are mandated with interpreting and applying the ESR standards under international law.

Taking as its starting point the delineation of ESR obligations in terms of the tripartite typology of respect, protect, and fulfill outlined by the Committee on Economic, Social and Cultural Rights (CESCR), this article considers how that framework (and the human rights treaty-monitoring bodies which employ it in their work) addresses privatization from an ESR perspective. Highlighting an excessive emphasis on the obligation to protect to the exclusion of other relevant levels of obligation, the author asserts that such an approach is reflective of a failure to conceptualize privatization and the state's role with regard to such properly-a failure that has very serious implications for the ability of the ESR framework as it stands to capture rights-harming actions in the context of privatization effectively. Arguing for a shift to the obligation to fulfill, the author contends this alternative approach would contribute significantly to the ability of ESR law as it stands to capture - and address - the full scope of state decision-making and (in)action at issue in situations of privatization.

The article opens with a discussion of privatization, its central role in prevailing economic globalization, and its ever more prevalent employment by states to varying degrees in giving effect to ESR in areas such as education, housing, and social security. Having provided a brief overview of the relationship between ESR and privatization in international human rights law (IHRL) terms, it considers how the existing international ESR schema and those who interpret and apply it address privatization. Turning to the tripartite typology, the article assesses how those bodies have developed and employed that framework to conceptualize and engage with privatization. It first traces the historic approach(es) of the UN treaty-monitoring bodies with an ESR mandate, before turning to the Committee on Economic, Social and Cultural Rights' most recent-and detailed-engagement with 
privatization in its General Comment No. 24 on State Obligations Under the International Covenant on Economic, Social and Cultural Rights in the Context of Business Activities. ${ }^{1}$ The article does so with the aim of evaluating the extent to which the predominant approach to the typology is capable of fully capturing ESR-harming actions in the context of privatization and to identify how this approach can/should be improved upon, and whether in fact in view of General Comment No. 24 the Committee is in fact moving in the right direction.

\section{PRIVATIZATION IN THE TWENTY-FIRST CENTURY}

The last thirty years have seen a massive shift towards a "smaller" or "shrinking" state, with governments ceding a range of functions previously regarded as "public" in nature through "privatization, outsourcing, and load shedding of public responsibilities." 2 Ironically, this notion of the reconfigured state $^{3}$ which has largely offloaded operational (if not legal) responsibility in terms of exercising functions related to human rights, has coincided with growing international and comparative recognition of ESR as legal standards imposing binding obligations on states in terms of their realization.

Privatization has been justified, indeed, heralded, on a range of instrumental grounds, including "efficiency, competition, innovation and deficit reduction."4 From an ESR perspective, it is arguable that where privatization results in more resources being available for ESR achievement, ${ }^{5}$ or more "expeditious" and "effective" realization of the different elements of $\mathrm{ESR}^{6}$ (through, for instance, the capture of the capacity or expertise of private actors), it might (perhaps even should) be welcomed. It is well beyond the scope of this article to describe the opportunities and risks that all of the myriad models of privatization

\footnotetext{
${ }^{1}$ CESCR, General Comment No. 24 on State Obligations Under the International Covenant on Economic, Social and Cultural Rights in the Context of Business Activities, paras. 15-16, 32-33, UN Doc. E/C.12/GC/24 (2017) [hereinafter CESCR GC No. 24].

${ }^{2}$ Chang Kil Lee \& David Strang, The International Diffusion of Public Sector Downsizing: Network Emulation and Theory-Driven Learning, in THE GlOBAL DIFFUSION OF MARKETS AND DEMOCRACY 141, 141 (Beth A. Simmons, Frank Dobbin \& Geoffrey Garrett eds., 2007).

${ }^{3}$ See DAvid Kinley, Civilising Globalisation: Human Rights AND the Global Economy 16 (2009) (noting that the consequences of the outsourcing of public functions are in fact more to do with the manner and form of public power, rather than with the diminution of its quantum, and that privatization correctly viewed involves a reconfiguration rather than a repudiation of the state).

${ }^{4}$ Danny Nicol, Swabian Housewives, Suffering Southerners: The Contestability of Justice as Exemplified by the Eurozone Crisis, in EUROPE's JUSTICE DEFICIT 156, 168 (Dimitry Kochenov, Gráinne de Búrca \& Andrew Williams eds., 2015).

${ }^{5}$ See International Covenant on Economic, Social and Cultural Rights art. 2, para. 1, Dec. 16, 1966, 999 U.N.T.S. 171 [hereinafter ICESCR].

${ }^{6}$ CESCR, General Comment No. 3: The Nature of States Parties' Obligations, para. 9, UN Doc. E/1991/23 (1990) [hereinafter CESCR GC No. 3].
} 
pose in terms of the myriad elements of ESR. ${ }^{7}$ However, the potential of privatization to contribute to "innovations and plural forms of social provision," thereby strengthening the state's "total response to people in need," is one that cannot be lightly dismissed by ESR advocates.

For the purposes of this article, I understand privatization to mean a shift towards provision by nongovernmental or nonstate actors of certain classes of goods and services, or performance by those actors of certain classes of functions, for the provision or performance of which, individuals have been accustomed to relying exclusively or mainly on state offices and agencies. ${ }^{9}$ Privatization covers a range of models and processes: these range from ownership of assets (purely private models); to models where the state retains ownership but contracts out an institution or delivery of a public service to private actors (i.e., where the operation of an institution or a service is privatized). ${ }^{10}$ Different models are used in different places and in different ESR-related sectors.

In her June 2010 report to the Human Rights Council, the then Independent Expert on the Issue of Human Rights Obligations Related to Access to Safe Drinking Water and Sanitation expressed a preference for the employment of the term "private sector participation" over "privatization" on the basis that the former term

is commonly used to refer to a broad spectrum of contractual arrangements between governments and the private sector that involve private companies in varying degrees in the provision of water and sanitation services. They differ according to the ownership of assets, the responsibility for capital investments, the allocation of risks, the responsibility for operations and maintenance, and the typical contract duration. For instance, while the model of concessions confers the management, risk and responsibility for investment on the private sector, private sector participation can also be limited to contracting out some aspects of management or service

\footnotetext{
${ }^{7}$ For useful discussions of the impacts of privatization on ESR including the rights to education, housing, social security, water, and the highest attainable standard of health, see PRIVATISATION AND HUMAN RIGHTS IN THE Age of Globalisation (Koen De Feyter \& Felipe Gómez Isa eds., 2005).

${ }^{8}$ Martha Minow, Public and Private Partnerships: Accounting for the New Religion, 116 HARV. L. REV. 1229, 1230 (2003). Minow is concerned with ensuring that privatization is subject to adequate public accountability requirements.

9 Adapted from Frank I. Michelman, Constitutionalism, Privatisation and Globalisation: Whither the Constitution?, 21 CARDOZO L. REv. 1063, 1063 (2000). I have replaced "organizations" with "actors" to avoid confusion with a specific kind of nonstate actors: "nongovernmental organizations."

${ }^{10}$ This is also known as "contracting out."
} 
provision. In many cases, the system cannot be designated as exclusively public or private but instead takes on a hybrid nature, also in the form of joint ventures. ${ }^{11}$

There is no doubt that a failure to acknowledge the complexity and multiple forms of private sector involvement in the delivery of ESR-related goods and services would render effective rights-based analyses of such forms inadequate. However, "privatization" is the term commonly used when considering the role of the private sector in the delivery of ESR-related services historically delivered by the state. Therefore, this article will employ it, albeit acknowledging that the term is being employed to cover a range of models and processes involving differing roles and levels of involvement for the private sector. This includes situations in which the private actor is a state-owned company with a legal entity distinct from the state. This article will not, however, focus on informal private sector actors who have not been formally mandated by the government to provide services. ${ }^{12}$ Nor will it address situations of "implicit privatization" in which privatization of sectors has occurred due to state cessation of public programs and disengagement of government from specific kinds of responsibilities. ${ }^{13}$ Finally, and relatedly, this article will not speak directly to situations in which liberalization and/or deregulation has resulted in increased private actor involvement in ESR realization, ${ }^{14}$ where the state has not specifically mandated such involvement. Admittedly, the analysis in the article will certainly have implications for these other forms of privatization to varying degrees but, given my criticisms of the failure of the bodies under consideration in this article to engage effectively with the complexities of privatization, I do not want to make the same mistake myself by employing a "one size fits all (forms of privatization)" model of analysis.

\footnotetext{
${ }^{11}$ Catarina de Albuquerque, Rep. of the Independent Expert on the Issue of Human Rights Obligations Related to Access to Safe Drinking Water and Sanitation, para. 9, UN Doc. A/HRC/15/31 (June 29, 2010) (footnote omitted).

${ }^{12}$ That is not to suggest that this is not a key issue in terms of delivery of some ESR-related services. For a discussion of the role played by this sector in the context of the right to water, see Catarina de Albuquerque \& Inga T. Winkler, Neither Friend nor Foe: Why the Commercialization of Water and Sanitation Services is not the Main Issue in the Realization of Human Rights, 17 BROWn J. WORLD AFF., no. 1, 2010, at 167.

${ }_{13}$ Paul Starr, The Meaning of Privatization, 6 YALE L. \& POL'Y REV. 6, 16 (1988). This implicit form of privatization may occur for a range of reasons, including a lack of state resources or capacity, or where the government is keen to remove itself from provision in a specific context.

${ }_{14}$ Borrowing from Cosmo Graham, I take the view that liberalization "means a process of introducing competition into an industry, while deregulation refers to relaxing the rules under which a sector conducts its activities." Cosmo Graham, Human Rights and the Privatisation of Public Utilities and Essential Services, in PRIVATISATION AND Human Rights In THE AGE OF Globalisation, supra note 7, at 33, 35.
} 
Privatization is frequently identified as a fundamental element of contemporary globalization (specifically, neoliberal economic globalization) ${ }^{15}$ and its bedfellow neoliberal economic orthodoxy. ${ }^{16}$ It went from being "an iconoclastic policy idea in Margaret Thatcher's 1979 British election manifesto to a major element of economic policy in both developed and developing countries over the course of twenty years." ${ }^{17}$ Against the backdrop of, and reflective of, the global diffusion of the political-economic ideology of privatization, ${ }^{18}$ the trend towards private sector involvement in areas with implications for human rights has been accelerated by factors including loan conditionality and the policies of international

\footnotetext{
${ }^{15}$ In its 1998 Statement on Globalization and its Impact on the Enjoyment of Economic, Social and Cultural Rights, the Committee on Economic, Social and Cultural Rights stated that globalization has

come to be closely associated with a variety of specific trends and policies including an increasing reliance upon the free market, a significant growth in the influence of international financial markets and institutions in determining the viability of national policy priorities, a diminution in the role of the state and the size of its budget, the privatization of various functions previously considered to be the exclusive domain of the state, the deregulation of a range of activities with a view to facilitating investment and rewarding individual initiative, and a corresponding increase in the role and even responsibilities attributed to private actors, both in the corporate sector, in particular to the transnational corporations, and in civil society.
}

CESCR, Rep. on the Eighteenth and Nineteenth Sessions, para. 515, UN Doc. E/C.12/1998/26 (Jan. 1, 1999) (emphasis added). The 1997 Maastricht Guidelines on Violations of Economic, Social and Cultural Rights also highlight that

[s]ince the end of the Cold War, there has been a trend in all regions of the world to reduce the role of the state and to rely on the market to resolve problems of human welfare, often in response to conditions generated by international and national financial markets and institutions and in an effort to attract investments from the multinational enterprises whose wealth and power exceed that of many states. It is no longer taken for granted that the realization of economic, social and cultural rights depends significantly on action by the state, although, as a matter of international law, the state remains ultimately responsible for guaranteeing the realization of these rights.

Maastricht Guidelines on Violations of Economic, Social and Cultural Rights, para. 2, contained in CESCR, Substantive Issues Arising in the Implementation of the International Covenant on Economic, Social and Cultural Rights, UN Doc. E/C.12/2000/13, at 16 (Oct. 2, 2000). One of the few treatments of privatization and extraterritorial obligations is provided in Manisuli Ssenyonjo, Reflections on State Obligations with Respect to Economic, Social and Cultural Rights in International Human Rights Law, 15 INT’L J. HUM. RTS. 969, 988-89 (2011).

${ }^{16}$ For useful overviews of the history and development of neoliberalism, see DAVID HARVEY, A BRIEF HISTORY of NeOliberalism (2005); Raymond Plant, The Neo-liberal State (2010); Daniel Stedman Jones, Masters of the Universe: HayeK, Friedman, AND the BirTh of NeOliberal Politics (2012). For a discussion of contemporary globalization as neoliberal globalization, see Paul O'Connell, Brave New World? Human Rights in the Era of Globalization, in INTERNATIONAL HuMAN RIGHTS LAW: SIX DECADES AFTER THE UDHR AND BEYOND 195, 198-204 (Mashood A. Baderin \& Manisuli Ssenyonjo eds., 2010). For a discussion of the development of privatization of public services in the context of neoliberalism, see COLIN CROUCH, THE StRANGE NON-DEATH OF NEO-LiBERALISM 20-21, 71-96 (2011).

${ }^{17}$ Beth A. Simmons, Frank Dobbin \& Geoffrey Garrett, Introduction: The Diffusion of Liberalization, in THE GLOBAL DIFFUSION OF MARKETS AND DEMOCRACY, supra note 2, at 1, 3. It should be noted however that privatization programs were adopted in a number of states prior to this. See Dónal Palcic \& EoIN ReEves, PRIVATISATION IN IRELAND: LESSONS FROM A EUROPEAN ECONOMY 12-15 (2011).

${ }^{18}$ For more on different perspectives on the causes of the global diffusion of privatization (including their own view premised on the "diffusion of the diffusers," i.e. US-trained economists), see Bruce Kogut \& J. Muir MacPherson, The Decision to Privatize: Economists and the Construction of Ideas and Policies, in THE GLOBAL DIFFUSION OF MARKETS AND DEMOCRACY, supra note 2, at 104. 
donors, international organizations ${ }^{19}$ and financial institutions ${ }^{20}$ (privatization is one of the central elements of the Washington Consensus), as well as economic constraints and international responses to the financial and economic crises of 2007-8. Things seem set fair for privatization: Agenda 2030 for Sustainable Development makes clear that the publicprivate partnerships (and the private sector more broadly) are to form a key part of the implementation of the Sustainable Development Goals ${ }^{21}$ - a point that is reiterated in some detail in the Addis Ababa Action Agenda on Financing. ${ }^{22}$

\section{PRIVATIZATION AND IHRL: A BRIEF OVERVIEW}

It is well established that privatization is not in and of itself precluded by IHRL. This is unsurprising given the strong role of nonstate actors in ESR-related goods and services provision at the time of drafting and ratification of the International Covenant on Economic, Social and Cultural Rights (ICESCR) and other treaties containing ESR-for instance, the part played by religious orders and other private actors in education in many countries - and the wide degree of discretion afforded to states in terms of the umbrella obligations imposed

\footnotetext{
${ }^{19}$ An example of this is what Nicol has described as "the EU's policy of compelling privatisation." Nicol, supra note 4, at 167. According to Nicol (id. at 167-68):

Article 106 TFEU, relating to the application of EU competition law to public undertakings, has been interpreted by the ECJ as removing the ability of Member States to reserve certain activities to their public sectors. This case-law has subsequently been reinforced and broadened by EU liberalisation directives ... Such liberalization brings in its wake an inevitable degree of privatisation, since it tends to be the private sector which takes advantage of liberalisation rights.

${ }^{20}$ These points have been made by the Independent Expert and then Special Rapporteur on the human rights to water and sanitation. See, e.g., Catarina de Albuquerque, supra note 11, para. 6 ("Private sector participation in developing countries should be understood in the context of donor approaches and international policies. International financial institutions, in particular, have promoted neo-liberal reforms advocating for States to reduce public spending and avoid significant investments. Some of the reforms leading to greater involvement of the private sector have been imposed through loan or aid conditionalities, debt reprogramming or loan forgiveness.") (footnotes omitted).

${ }^{21}$ See, e.g., UN President of the G.A., Transforming Our World: The 2030 Agenda for Sustainable Development, Goal 17.17, para. 43 (Aug. 11, 2015), http://www.un.org/pga/wpcontent/uploads/sites/3/2015/08/120815_outcome-document-of-Summit-for-adoption-of-the-post-2015-

development-agenda.pdf. It should be noted that the Outcome document interprets the private sector with a role in the implementation of the Agenda broadly as "ranging from micro-enterprises to cooperatives to multinationals, and that of civil society organizations and philanthropic organizations." Id. para. 41. Concern has been expressed by civil society, trade unions, and social movements about the privatization, public-private partnerships, and corporate capture in the "Global Partnership" envisaged by the Sustainable Development Goals - and the impact of such on sustainability and inequality. See, e.g., Spotlight on Sustainable Development: Reclaiming Policies for the Public (2017), https://www.2030spotlight.org/en/book/1165/chapter/0101reclaiming-public-policy-space-sdgs (last visited July 12, 2017).

${ }^{22}$ G.A. Res. 69/313, para. 48 (July 27, 2015).
} 
by ICESCR and other ESR-containing instruments. ${ }^{23}$ Indeed, the existence of private provision of ESR-related goods and services was recognized by the drafters of ICESCR to the extent of that instrument providing that states can only interfere with the liberty of nonstate actors to establish and direct educational institutions in very limited circumstances. ${ }^{24} \mathrm{As}$ discussed below, the IHRL body with the greatest authority vis-à-vis the interpretation and application of ESR, the UN Committee on Economic, Social and Cultural Rights, has emphasized that the rights recognized in ICESCR are susceptible of realization within the context of a wide variety of economic and political systems, ${ }^{25}$ that privatization may be one of the "enabling strategies" to be encouraged by states to supply ESR goods and services deficits, ${ }^{26}$ and that private provision is very much a feature of the ESR-related goods and service landscape. That said, there has been growing concern globally about the human rights implications of private sector participation in the delivery of services traditionally associated with the state in a range of contexts, including prison operations, ${ }^{27}$ social care and child protection, ${ }^{28}$ and immigration. ${ }^{29}$

Nowak is undoubtedly correct in noting that human rights are not "neutral" on privatization on the basis that effective implementation of international human rights

${ }^{23}$ See, e.g., ICESCR, supra note 5, art. 2, para. 1; Convention on the Rights of the Child art. 4, Nov. 20, 1989, 1577 U.N.T.S. 3 [hereinafter CRC]; Convention on the Rights of Persons with Disabilities art. 4, para. 2, Dec. 13, 2006, 2515 U.N.T.S. 3.

${ }^{24}$ See ICESCR, supra note 5, art. 13, para. 4. See also CRC, supra note 23, art. 29, para. 2, for a similar provision.

${ }^{25}$ CESCR GC No. 3, supra note 6, para. 8.

${ }^{26}$ See, e.g., CESCR, General Comment No. 4: The Right to Adequate Housing, paras. 14-15, UN Doc. E/1992/23 (1991) [hereinafter CESCR GC No. 4].

${ }^{27}$ See, for example, the work of the ACLU National Prison Project focused on private prisons in the US. In August 2016, the US Justice Department issued a memo to the Federal Bureau of Prisons telling them to either decline to renew the contracts for private prison operators when they expire or "substantially reduce" their "scope in a manner consistent with law and the overall decline of the Bureau's inmate population." Memorandum from the Office of the Deputy Attorney General, for the Acting Director Federal Bureau of Prisons (Aug. 18, 2016), http://www.justice.gov/archives/opa/file/886311/download. The memo noted that "[private prisons] simply do not provide the same level of correctional services, programs, and resources; they do not save substantially on costs." Id. On 21 February 2017, Attorney General Jeff Sessions rescinded this memo.

${ }^{28}$ See, for example, debates around government moves to privatize child protection and other social care services in the UK. See, e.g., Andy McNicoll, Minister: "We Won't Privatise Child Protection or Politicise Social Work," COMMUNITYCARE (July 7, 2016), http://www.communitycare.co.uk/2016/07/07/minister-wontprivatise-child-protection-politicise-social-work/; Patrick Butler, Labour Fears Potential Privatisation of Child Protection Services, GUARDIAN (June 13, 2016), http://www.theguardian.com/society/2016/jun/13/labour-fearspotential-privatisation-of-child-protection-services.

${ }^{29}$ See, for example, the Nauru files, published by the Guardian on 10 August 2016, which provided details of the human rights violations experienced by child (and adult) detainees in the Australian detention camp ("Regional Processing Centre") on Nauru. The Nauru Files, GUARDIAN, http://www.theguardian.com/australianews/ng-interactive/2016/aug/10/the-nauru-files-the-lives-of-asylum-seekers-in-detention-detailed-in-a-uniquedatabase-interactive (last visited July 12, 2017). This camp is run by a private company, Broadspectrum, with health and other services being provided to inmates by other private companies. See, e.g., Amnesty, Australia: Appalling Abuse, Neglect of Refugees on Nauru (Aug. 2, 2016), http://www.amnesty.org/en/latest/news/2016/08/australia-abuse-neglect-of-refugees-on-nauru/. 
obligations requires states and the international community to develop, maintain, and progressively improve a certain level of public infrastructure in order to enable all human beings to effectively enjoy and exercise all human rights. ${ }^{30}$ However, given that privatization is permissible in terms of IHRL, this article - which is focused on that body of law-seeks to identify the parameters of rights-compliant privatization, rather than to reject it out of hand as a violation of human rights per se. Privatization can clearly violate ESR in terms of the way in which it is carried out (i.e., through the noncompliance of privatization process with human rights) and in terms of its outcomes (i.e., the impact of privatization on the enjoyment of human rights). ${ }^{31}$ While strong views are frequently expressed about certain human rightsrelated services and functions being fundamentally and inherently "governmental" or "public" in nature, ${ }^{32}$ such views are challenged by the breadth and scope of privatization in practice. From an ESR perspective specifically, privatized provision is becoming ever more common in the context of goods and services related to ESR, including those related to health, ${ }^{33}$ education, ${ }^{34}$ water, and housing. ${ }^{35}$

\footnotetext{
${ }^{30}$ Manfred Nowak, Human Rights or Global Capitalism: The Limits of Privatization 2 (2017). The ICESCR, for instance, is clearly based on the model of an advanced welfare state, $i d$. at 42 . For a similar view that human rights, in particular ESR, "require significant state involvement for them to be fully and meaningfully realized," see O'Connell, supra note 16, at 209.

${ }^{31}$ Concerns about privatization in the context of ESR are of course not just limited to the noncompliance of specific privatization processes and outcomes with ESR; rather, they extend to concerns about what privatization may mean for ESR - and the processes and institutions necessary to give effect to those rights - in the broader contemporary legal and political context. Such concerns include the implications of privatization for public engagement and shared responsibility for rights achievement (resulting in an erosion of a sense of rights as legal entitlements to be guaranteed by the polity), for public accountability (resulting in a diminution in de facto (if not legal) state responsibility for rights delivery), and for the marketization and commodification of ESR (resulting in a reduced sense of their status as public goods and/or as legal rights premised on human dignity). These issues and more are explored further in Aoife Nolan, Privatisation: The Dangers for Human Rights (unpublished working paper) (on file with author).

${ }^{32}$ For an example of a judicial view on a human rights-related function being inherently governmental in nature, see the decision of the Israeli Supreme Court in HCJ 2605/05 The Human Rights Division, The Academic Center for Law and Business v. Minister of Finance (Nov. 19, 2009), holding that the human rights of prison inmates are violated ipso facto by the transfer of powers to manage and operate a prison from the state to a private concessionaire that is a profitmaking enterprise. Here the Court discussed in detail the "monopoly given to the state to use force in general, and to deny the personal liberty of individuals in order to enforce the criminal law in particular." Id. para. 27. For an example of political claim that a rights-related function is inherently governmental, see the work of the Irish Right to Water Campaign on the right to water, who have sought a constitutional amendment in Ireland providing that: "The Government shall be collectively responsible for the protection, management and maintenance of the public water system. The Government shall ensure in the public interest that this resource remains in public ownership and management." Right2Water, Policy $\begin{array}{llllll}\text { Principles for a Progressive } & \text { Irish }\end{array}$ http://www.mandate.ie/Documents/111930_12796_R2W-Unions_Policies_A5.pdf (last visited July 12, 2017). For a thoughtful discussion of "public" services in the context of ESR, see Marlies Hesselman, Antenor Hallo de Wolf \& Brigit Toebes, Common Challenges for Socio-Economic Human Rights and Essential Public Services Provision, in Socio-EConomic Human Rights in Essential Public Services Provision 1, 4-6 (Marlies Hesselman, Antenor Hallo de Wolf \& Brigit Toebes eds., 2017).

${ }^{33}$ See, e.g., Interim Rep. of the Special Rapporteur on the Right of Everyone to the Enjoyment of the Highest Attainable Standard of Physical and Mental Health (2012), para. 3, UN Doc. A/67/302 (Aug. 13, 2012) (highlighting "the global trend towards privatization in health systems"). For more on privatization and the right
} 
This article takes as its starting point the fact that states are the key actors for the purposes of IHRL and hence the discussion below. ${ }^{36}$ That is not to ignore recent moves in relation to the development of direct obligations on the part of nonstate actors in terms of intentional human rights law, including the establishment of the UN Open-Ended Intergovernmental Working Group on Transnational Corporations and Other Business Enterprises with Respect to Human Rights, with a mandate to "elaborate an international legally binding instrument to regulate, in international human rights law, the activities of transnational corporations and other business enterprises. ${ }^{, 37}$ Nor is it to set to one side the potential of ongoing efforts to delineate the responsibilities of transnational corporations with regard to international law through means such as the Ruggie Guiding Principles on Business and Human Rights ${ }^{38}$ or evolving understandings of the obligations of international organizations, such as international financial institutions, under IHRL, particularly in the context of extraterritorial obligations. ${ }^{39}$ As things stand, however, ESR - and the obligations imposed by them-are still predominantly conceptualized in terms of state action (and inaction) by scholars, advocates, states, and the international bodies responsible for applying

to health, see Audrey R. Chapman, Global HeAlth, Human Rights AND tHe Challenge OF Neoliberal POLICIES (2016).

${ }^{34}$ See, e.g., Kishore Singh, Rep. of the Special Rapporteur on the Right to Education, para. 32, UN Doc. A/69/402 (Sept. 24, 2014) (highlighting "the explosive growth of privatized education").

${ }^{35}$ See, e.g., Raquel Rolnik, Rep. of the Special Rapporteur on Adequate Housing as a Component of the Right to an Adequate Standard of Living and on the Right to Non-discrimination in This Context, para. 2, UN Doc. A/67/286 (Aug. 10, 2012) (highlighting the shift in housing policy from the late 1970s on, "starting with North America and Europe, followed later by developing countries in Latin America, Asia, Africa and by formerly planned economies" which, "supported by predominant economic doctrine, called for the transfer of activities from State control to the private sector and for unrestricted free markets and free trade").

${ }^{36}$ For useful overviews of the position of nonstate actors in relation to IHRL, see Jan Arno Hessbruegge, Human Rights Violations Arising from Conduct of Non-state Actors, 11 BUfF. HUM. RTS. L. REv. 21 (2005); John H. Knox, Horizontal Human Rights Law, 102 AM. J. INT’L L. 1, 19 n.86 (2008); Manisuli Ssenyonjo, The Applicability of International Human Rights Law to Non-state Actors: What Relevance to Economic, Social and Cultural Rights?, 12 INT'L J. HUM. RTS. 725 (2008).

${ }^{37}$ Human Rights Council Res. 26/9, para. 1, UN Doc. A/HRC/RES/26/9 (July 14, 2014). Details of the Working Group's work so far are available at http://www.ohchr.org/EN/HRBodies/HRC/WGTransCorp/Pages/IGWGOnTNC.aspx (last visited July 12, 2017). For a useful overview of the political feasibility of options for a legally binding international instrument in the area of business and human rights, see Olivier De Schutter, Towards a New Treaty on Business and Human Rights, 1 Bus. \& HuM. RTS. J. 41 (2016).

${ }^{38}$ John Ruggie, Guiding Principles on Business and Human Rights: Implementing the United Nations "Protect, Respect, and Remedy" Framework, UN Doc. A/HRC/17/31 (Mar. 21, 2011). For details on the work of the Special Procedure mandate tasked with the implementation of the Principles, see http://www.ohchr.org/EN/Issues/Business/Pages/WGHRandtransnationalcorporationsandotherbusiness.aspx (last visited July 12, 2017). For a useful collection of academic treatments of the Guiding Principles and issues arising in relation to them, see Business AND HUMAN RightS: From PRINCIPLES TO PRACTICE (Dorothée Baumann-Pauly \& Justine Nolan eds., 2016).

39 See, e.g., CESCR, Statement on Public Debt, Austerity Measures and the International Covenant on Economic, Social and Cultural Rights, UN Doc. E/C.12/2016/1 (July 22, 2016). See also Maastricht Principles on Extraterritorial Obligations of States in the Area of Economic, Social and Cultural Rights, Principle 16, https://www.fidh.org/IMG/pdf/maastricht-eto-principles-uk_web.pdf (last visited July 12, 2017). 
ESR standards to the privatization context. ${ }^{40}$ International enforcement mechanisms with regard to ESR in a privatization context are similarly predominantly state-focused. Furthermore, even if there was to be a shift toward widespread recognition of direct obligations of nonstate actors under IHRL, states would ultimately still be responsible for ensuring effective remedies; as such, state responsibility will always be in the background.

The fact that the state remains a key player in both enabling and implementing privatization also renders a state-centric focus appropriate: it is important to recognize that privatization cannot occur without state consent, with states taking the necessary action to delegate or divest (albeit that they may not be acting autonomously in exercising a decision to implement such policies). This is reflected in increasingly nuanced understandings of the role of the state in creating and maintaining the public/private divide in the ESR context. For instance, in the UK, food banks which deliver right to food-related goods are private entities (subject to state regulation through, inter alia, charities law and local environmental health regulations). At the same time, most of these private bodies operate on a voucher system, with vouchers being issued by state actors including public health, education, and social workers. ${ }^{41}$ As such, while food banks and their activities are officially located in the "private sphere," they are a key means by which public sector actors ensure food access. There is a tendency in the literature to focus on the "weakening state" in the context of economic globalization, and the relative power differences between (particularly poorer) states and nonstate actors such as transnational corporations; in fact, it is arguable that globalization has not resulted in a lack of state power (as Harvey notes, "neoliberalism cannot function without a strong state and strong market and legal institutions") ${ }^{42}$ so much as a choice on the part of the state about how and through which intermediaries power should be exercised ${ }^{43}$ - as well as for what purposes. It is thus appropriate and important to keep an eye on those choicesand their ESR compliance-rather than focusing exclusively on mechanisms whose current ability to ensure effective accountability in the context of ESR-harming privatization is, at best, open to question. The article thus plays by the rules of IHRL as they stand but fully

\footnotetext{
${ }^{40}$ See, for example, the work of the CESCR and the Committee on the Rights of the Child discussed below.

${ }^{41}$ For more on the operation of foodbanks, see, for example, Jane Perry, Martin Williams, Tom Sefton \& Moussa Haddad, Emergency Use Only: Understanding and Reducing the Use of Food Banks in the UK (CPAG, Church of England, Oxfam GB \& Trussell Trust, Nov. 2014), https://www.trusselltrust.org/wpcontent/uploads/sites/2/2016/01/foodbank-report.pdf.

${ }^{42}$ HARVEY, supra note 16 , at 117.

${ }^{43}$ Jessie Hohmann, Principle, Politics and Practice: The Role of UN Special Rapporteurs on the Right to Adequate Housing in the Development of the Right to Housing in International Law, in THE UNITED NATIONS SPECIAL PROCEDURES System 271, 287 (Aoife Nolan, Rosa Freedman \& Thérèse Murphy eds., 2017), citing SASkia SASSEN, TERritory, Authority, Rights: From MedieVAl to Global Assemblages 319 (2006).
} 
acknowledges that these rules are under review and indeed strongly merit revision with regard to their effective capture of ESR-affecting private actors.

A final point before we move on: a significant thing to note in relation to the forms of privatization considered in this article is the multiplicity of stages or loci of state decisionmaking and (in)action that are at issue in any privatization situation. When it comes to decision-making in the context of state divestiture or contracting out of ownership or management (the key forms of privatization under consideration in this article), the state has in human rights terms a role before, during, and after privatization. ${ }^{44}$ State decisions/action prior to privatization include the decision to examine the possibility of privatization, the subsequent move to privatize and the delineation of the privatization model to be adopted in the specific instance (this might include both the specific form that privatization should take and the identification of mechanisms and benchmarks for the assessment of the "success" of privatization). State decision-making actions during privatization will primarily focus on ensuring the implementation of that privatization in line with pre-established plans. The role of the state post-privatization will be primarily one of supervision and regulation - to ensure that private actors conform to their undertakings and functions and to assess the overall success of privatization in terms of pre-determined standards. Any adequate conceptualization of privatization must recognize the existence of these different stages of decision-making and action - and the relevance of ESR and the obligations imposed by such rights to all of them. ${ }^{45}$

\section{PRIVATIZATION AND ESR OBLIGATIONS}

In considering how the rules of IHRL serve to capture and challenge negative privatization-related impacts on ESR, our starting point is the ESR obligations framework;

\footnotetext{
44 That is not to suggest that the state decision-making in relation to privatization occurs in isolation; as made clear above, other actors such as supranational financial institutions and corporate actors may have a significant role in motivating or shaping privatization arrangements. However, as stated above, this paper focuses on the role of the state for the purposes of human rights obligations.

${ }^{45}$ It must also of course recognize potential limitations on state capacity in terms of its ability to give effect to its obligations (in terms of effective institutions or available resources, for instance), as well as the roles and responsibilities of other actors in relation to privatization. This paper will not however engage extensively with these issues, reserving them to future work rooted in specific instances of privatization where they can be explored more fully. This paper is focused on the shortcoming in terms of the ESR framework in relation to privatization, rather than the practical challenges faced by states in giving effect to the obligations in terms of that framework.
} 
that is, the hard law ESR framework set out in the core UN human rights treaties and its interpretation by the relevant quasi-judicial treaty-monitoring bodies. ${ }^{46}$

\section{A. Painting a Partial Picture of Obligation: The Work of the CESCR on Privatization}

The first — and indeed key—body to consider is the Committee on Economic, Social and Cultural Rights. The Committee has not ignored the role of private actors with regard to the realization of ESR. Eight General Comments contain discrete chapters or sections explicitly addressing "obligations of actors other than states," 47 as well as a wide range of references to private/nonstate actors that demonstrate that privatization is very much part of accepted delivery methods of ESR. ${ }^{48}$ The Committee has made clear in several General Comments the need for states to build a consideration of collaboration with private actors (and hence implicitly privatization) into what it has termed "framework laws" for the

\footnotetext{
${ }^{46}$ Clearly other actors such as Special Procedures have a role to play in developing understandings of the scope of ESR obligations. (For an example in the context of the right to sanitation, see Inga T. Winkler \& Catarina de Albuquerque, Doing It All and Doing It Well? A Mandate's Challenges in terms of Cooperation, Fundraising and Maintaining Independence, in THE UNITED NATIONS SPECIAL PROCEDURES SYSTEM, supra note 43, at 188). However, this paper will focus on treaty-monitoring bodies as those that are the actors mandated to monitor the ESR obligations as set out under the treaties specifically, whereas the mandates of Special Procedures frequently do not map directly on to specific human rights instruments. For examples of Special Procedures addressing privatization and ESR from the perspective of the tripartite typology in their reports, see Kishore Singh, Rep. of the Special Rapporteur on the Right to Education, para. 75, UN Doc. A/70/342 (Aug. 26, 2015); Catarina de Albuquerque, Rep. of the Special Rapporteur on the Human Right to Safe Drinking Water and Sanitation, esp. paras. 25-34, UN Doc. A/HRC/27/55 (June 30, 2014).

${ }^{47}$ See CESCR, General Comment No. 13: The Right to Education, ch. III, UN Doc. E/C.12/1999/10 (Dec. 8, 1999) [hereinafter CESCR GC No. 13]; CESCR, General Comment No. 14: The Right to the Highest Attainable Standard of Health, ch. V, UN Doc. E/C.12/2000/4 (Aug. 11, 2000) [hereinafter CESCR GC No. 14]; CESCR, General Comment No. 15: The Right to Water, ch. VI, UN Doc. E/C.12/2002/11 (Jan. 20, 2003) [hereinafter CESCR GC No. 15]; CESCR, General Comment No. 17: The Right of Everyone to Benefit from the Protection of the Moral and Material Interests Resulting from any Scientific, Literary or Artistic Production of Which He or She is the Author, ch. VI, UN Doc. E/C.12/GC/17 (Jan. 12, 2006) [hereinafter CESCR GC No. 17]; CESCR, General Comment No. 18: The Right to Work, ch. VI, UN Doc. E/C.12/GC/18 (Feb. 6, 2006) [hereinafter CESCR GC No. 18]; CESCR, General Comment No. 19: The Right to Social Security, ch. VI, UN Doc. E/C.12/GC/19 (Feb. 4, 2008) [hereinafter CESCR GC No. 19]; CESCR, General Comment No. 21: Right of Everyone to Take Part in Cultural Life, ch. IV, UN Doc. E/C.12/GC/21 (Dec. 21, 2009) [hereinafter CESCR GC No. 21]; CESCR, General Comment No. 23 (2016) on the Right to Just and Favourable Conditions of Work, ch. III(E), UN Doc. E/C.12/GC/23 (Apr. 27, 2016) [hereinafter CESCR GC No. 23]. It is notable that a recent General Comment of the Committee refers to "the responsibilities" of nonstate actors, clearly echoing the language of the Guiding Principles. See CESCR GC No. 23, paras. 51, 74-75. This is despite the issues that arise in relation to such responsibilities being unenforceable in terms of IHRL - the framework within which the Committee operates.

${ }^{48}$ See, e.g., CESCR GC No. 4, supra note 26, para. 14 (envisaging enabling strategies including involvement of the private sector in satisfying housing deficits); CESCR, General Comment No. 7: The Right to Adequate Housing: Forced Evictions, para. 9, UN Doc. E/1998/22 (1997) [hereinafter CESCR GC No. 7] (highlighting increasing trend in some states towards the government reducing its responsibilities in the housing sector); CESCR GC No. 19, supra note 47, paras. 5, 13 (envisaging private social security schemes and private and mixed healthcare plans). General Comment No. 14 on the right to health makes repeated reference to the role of private health providers including a reference to the state's obligations including "the provision of a public, private or mixed health insurance system which is affordable to all." CESCR GC No. 14, supra note 47, para. 36.
} 
operationalization of ESR. ${ }^{49}$ In its General Comment No. 4 on the Right to Adequate Housing, for example, the Committee stated that

[m] easures designed to satisfy a State party's obligations in respect of the right to adequate housing may reflect whatever mix of public and private sector measures considered appropriate. While in some States public financing of housing might most usefully be spent on direct construction of new housing, in most cases, experience has shown the inability of Governments to fully satisfy housing deficits with publicly built housing. The promotion by States parties of "enabling strategies", combined with a full commitment to obligations under the right to adequate housing, should thus be encouraged. In essence, the obligation is to demonstrate that, in aggregate, the measures being taken are sufficient to realize the right for every individual in the shortest possible time in accordance with the maximum of available resources. ${ }^{50}$

That said, the Committee has made clear its awareness of the potential negative implications of privatization for ESR enjoyment: emphasizing in its General Comment No. 22 on the Right to Sexual and Reproductive Health, for instance, that international assistance should not "push recipient countries to adopt models of privatization." ${ }^{51}$ In other General Comments, the Committee's concerns about the implications of privatization for equality and nondiscrimination in terms of ESR enjoyment are evident; examples include a statement in relation to the rights of persons with disabilities that "[i]n a context in which arrangements for the provision of public services are increasingly being privatized and in which the free market is being relied on to an ever greater extent, it is essential that private employers, private suppliers of goods and services, and other non-public entities be subject to both nondiscrimination and equality norms, $" 52$ and highlighting that the obligation of states to monitor and regulate the conduct of nonstate actors to ensure that they do not violate the equal right of

\footnotetext{
${ }^{49}$ See, e.g., CESCR GC No. 14, supra note 47, para. 56; CESCR GC No. 15, supra note 47, para. 50; CESCR GC No. 19, supra note 47, para. 72.

${ }^{50}$ CESCR GC No. 4, supra note 26, para. 14.

${ }^{51}$ CESCR, General Comment No. 22 (2016) on the Right to Sexual and Reproductive Health, para. 53, UN Doc. E/C.12/GC/22 (May 2, 2016) [hereinafter CESCR GC No. 22].

${ }^{52}$ CESCR, General Comment No. 5: Persons with Disabilities, para. 11, UN Doc. E/1995/22 (1994) [hereinafter CESCR GC No. 5]. The Committee continued to say (id. para. 12):

In the absence of government intervention there will always be instances in which the operation of the free market will produce unsatisfactory results for persons with disabilities, either individually or as a group, and in such circumstances it is incumbent on Governments to step in and take appropriate measures to temper, complement, compensate for, or override the results produced by market forces.

This point was reiterated in CESCR GC No. 14, supra note 47, para. 26.
} 
men and women to enjoy economic, social, and cultural rights applies "in cases where public services have been partially or fully privatized." ${ }^{, 53}$

Despite these comments, the Committee has not engaged with privatization forms, processes, outputs, outcomes, and rights impacts in depth in its General Comments or other work. While there are a number of questions directed towards states parties related to privatization in its reporting guidelines, ${ }^{54}$ the Committee's statements on privatization in its Concluding Observations appear to be largely ad hoc ${ }^{55}$ with recent, more consistent references focused on education, reflecting the advocacy of two nongovernmental organizations on this point. ${ }^{56}$ In his 2012 analysis of the CESCR's approach to privatization in its Concluding Observations, Hallo de Wolf found that " $[t]$ he broad concerns of the CESCR regarding privatization are very obvious and the perceived threats with respect to the rights guaranteed in the ICESCR should be duly noted. However, the CESCR's way of dealing with privatization leaves something to be desired." 57 In none of the Concluding Observations considered by Hallo de Wolf did the Committee note how privatization affected the rights concerned; rather, it limited itself to observing that privatization may have (or has had) some type of negative effect upon the enjoyment of a right without properly evidencing these conclusions with data or specific cases. ${ }^{58}$

The Committee's more recent work focused on the right to education has it is true moved beyond this somewhat, with both its questions to states on privatization and its Concluding Observations focusing on the impact of privatization on specific elements of that

\footnotetext{
${ }^{53}$ CESCR, General Comment No. 16: The Equal Right of Men and Women to the Enjoyment of All Economic, Social and Cultural Rights, para. 20, UN Doc. E/C.12/2005/4 (Aug. 11, 2005) [hereinafter CESCR GC No. 16].

${ }^{54}$ CESCR, Guidelines on Treaty-Specific Documents to be Submitted by States Parties Under Articles 16 and 17 of the International Covenant on Economic, Social and Cultural Rights, para. 15(b), UN Doc. E/C.12/2008/2 (Mar. 24, 2009) ("The impact of measures to facilitate re-employment of workers, especially women and longterm unemployed workers, who are made redundant as a result of privatization, downsizing and economic restructuring of public and private enterprises."); id. para. 30 ("Indicate whether the public social security schemes described above are supplemented by any private schemes or informal arrangements. If so, describe these schemes and arrangements and their inter-relationship with the public schemes."); id. para. 48(c) ("The measures taken to ensure that water services, whether privately or publicly provided, are affordable for everyone."); id. para. 56(b) ("That the costs of health-care services and health insurance, whether privately or publicly provided, are affordable for everyone, including for socially disadvantaged groups.”).

${ }_{55}$ For an excellent overview of the Committee's reference to privatization in its Concluding Observations up until November 2014, see GIESCR, Privatisation and Economic, Social and Cultural Rights (Nov. 2014) (on file with author).

56 The nongovernmental organizations in question are the Global Initiative on Economic, Social and Cultural Rights and the Right to Education Project. For more on the CESCR's statements on education and privatization, see Global Initiative on Economic, Social and Cultural Rights, Human Rights Bodies Statements on Private Education September 2014 - June 2017: Synthesis Paper - Version 8 (June 2017), http://globalinitiativeescr.org/wp-content/uploads/2016/10/GIESCR-CRC_CESCR_CEDAW-synthesis-statements-on-private-actorsin-education.pdf [hereinafter GIESCR Synthesis Paper].

57 ANTENOR Hallo DE WOLF, RECONCILING PRIVATIZATION With HuMAN Rights 379 (2012).

${ }^{58} I d$. at 379.
} 
right. ${ }^{59}$ There is however still very limited evidence of engagement with the specific forms and processes of privatization: key state decision-making bodies go unexamined, different models of privatization are not identified and critiqued. ${ }^{60}$ While this lack of analysis is to some degree attributable to the constraints (time, information, and reporting word count) faced by the Committee in the state reporting process, the Committee's much more effective engagement with other areas in its Concluding Observations makes clear that much more could be done.

Nor did the Committee's General Comments or Statements prior to its important General Comment No. 24 in June 2017 (on which more shortly) address privatization in detail-particularly strikingly its 2011 Statement on the Obligations of States Parties Regarding the Corporate Sector and Economic, Social and Cultural Rights contained no express mention of privatization. ${ }^{61}$ There thus remained a range of unanswered questions in terms of how the ICESCR framework captures rights-harming privatization processes and actions.

In considering in more detail the ability of the ESR framework to address privatization, this section will focus on a specific albeit very important general area: the Committee's treatment of privatization in the context of the tripartite typology that it has evolved as part of its General Comments. ${ }^{62}$ This typology forms a central part of the Committee's work. It has been a feature of all General Comments on substantive rights since its 1999 one on the right to food ${ }^{63}$ - and has served as primary framework on the part of the Committee for the purposes of delineating obligations imposed on states, including in the context of privatization. The typology has been highly influential, being employed extensively by academics, advocates, and (as will be discussed below) other UN actors in their work on ESR. As such, it is a central element of the normative ESR framework outlined

\footnotetext{
${ }^{59}$ For more detail, see, for example, GIESCR Synthesis Paper, supra note 56, at 8-9.

${ }^{60}$ For instance, in its recent Concluding Observations on Australia, the Committee expressed concern that private companies, such as the service providers in the regional processing centers for asylum-seekers in Nauru and Papua New Guinea, were responsible for serious human rights violations, and about the lack of proper and independent investigation and complaints mechanisms. See CESCR, Concluding Observations on the Fifth Periodic Report of Australia, para. 13, UN Doc. E/C.12/AUS/CO/5 (July 11, 2017). It did not, however, discuss the specific arrangements or the obligations at issue bar the right to a remedy in terms of Article 2(1) ICESCR.

${ }^{61}$ CESCR, UN Doc. E/C.12/2011/1 (May 20, 2011). There is a reference to states parties being required "to obtain the corporate sector's support to the realization of economic, social and cultural rights," id. para. 6, in the context of a discussion of the obligation to fulfill but this is a far cry from a clear reference to privatization.

${ }^{62}$ The question of maximum available resources was previously addressed in Aoife Nolan, Budget Analysis and Economic and Social Rights, in ECONOMIC, SOcial, AND CUltural Rights In InTERnATIONAL LAW: CONTEMPORARY ISSUES AND CHALLENGES 369 (Eibe Riedel, Gilles Giacca \& Christophe Golay eds., 2014).

${ }^{63}$ CESCR, General Comment No. 12: The Right to Adequate Food, para. 15, UN Doc. E/C.12/1999/5 (May 12, 1999) [hereinafter CESCR GC No. 12].
} 
by the Committee, reflecting that body's conceptualization of ESR and their corresponding obligations.

The typology has evolved over time ${ }^{64}$ but the key elements can be summed up as follows: the obligation to respect requires states not to interfere with the enjoyment of ESR; ${ }^{65}$ the obligation to protect requires states to take steps to prevent others from interfering with the enjoyment of ESR; ${ }^{66}$ and the obligation to fulfill requires states to adopt appropriate legislative, administrative, budgetary, judicial, promotional, and other measures towards the full realization of ESR ${ }^{67}$ Incorporating the obligations to promote, facilitate, and provide, ${ }^{68}$ the obligation to fulfill is strongly linked with the umbrella obligation set out in Article 2(1) ICESCR of progressive realization of ESR to the maximum extent of state resources, ${ }^{69}$ and the ultimate goal of ICESCR: the full realization of ESR.

When focusing on the state's duty with regard to private actors, in the context of the tripartite typology, the Committee has generally based its analysis on the obligation to protect; ${ }^{70}$ that is, as the Committee has frequently put it, the state's obligation to prevent "interference" by third parties with "enjoyment" of ESR. ${ }^{71}$ In a similar vein, much of the Committee's discussion of the role of the state vis-à-vis the satisfaction of ESR-related needs by private actors has centered on the issue of the regulation of such actors - crucially again primarily in the context of discussions on the obligation to protect. ${ }^{72}$ The Committee's most

\footnotetext{
${ }^{64}$ A key point of evolution has been the different elements of the obligation to fulfill outlined by the Committee in its work. For more details, see Ida Elisabeth Koch, Dichotomies, Trichotomies or Waves of Duties?, 5 HuM. RTS. L. REV. 81 (2005).

${ }^{65}$ Maastricht Guidelines on Violations of Economic, Social and Cultural Rights, supra note 15, para. 6.

${ }^{66}$ For more on the definition of the obligation to protect, see below.

${ }^{67}$ Paraphrased from CESCR GC No. 14, supra note 47, para. 33.

${ }^{68}$ See, e.g., id. para. 37.

${ }^{69}$ The linkage between the obligation to fulfill and full realization is made explicit by the Committee in its General Comment on the right to health. See id. para. 36.

${ }^{70}$ See CESCR GC No. 12, supra note 63, para. 15; CESCR GC No. 13, supra note 47, para. 50; CESCR GC No. 14, supra note 47, para. 35; CESCR GC No. 16, supra note 53, paras. 19-20; CESCR GC No. 17, supra note 47, para. 32; CESCR GC No. 18, supra note 47, para. 25; CESCR GC No. 19, supra note 47, paras. 45-46; CESCR, General Comment No. 20: Non-discrimination in Economic, Social and Cultural Rights, para. 11, UN Doc. E/C.12/GC/20 (July 2, 2009); CESCR GC No. 21, supra note 47, para. 50(b); CESCR GC No. 22, supra note 51, paras. 42-43, 60. For more on the obligation to protect, see Aoife Nolan, Addressing Economic and Social Rights Violations by Non-state Actors Through the Role of the State: A Comparison of Regional Approaches to the "Obligation to Protect," 9 HuM. RTS. L. REV. 225 (2009).

${ }^{71}$ See infra text accompanying notes 90-91.

${ }^{72}$ See, e.g., CESCR GC No. 7, supra note 48, para. 9; CESCR GC No. 12, supra note 63, paras. 19, 27 (in the context of discussion of violations caused by the direct action of states "or other entities insufficiently regulated by states"); CESCR GC No. 13, supra note 47, para. 59 (in the context of discussion of "acts of omission"); CESCR GC No. 14, supra note 47, para. 26 (in the context of discussing the requirement of states to ensure that private health providers comply with the principle of nondiscrimination), and para. 49 (in the context of discussion of "acts of omission"); CESCR GC No. 15, supra note 47, para. 44(b); CESCR GC No. 16, supra note 53, para. 20; CESCR GC No. 17, supra note 47, paras. 32, 55; CESCR GC No. 18, supra note 47, para. 35; CESCR GC No. 19, supra note 47, para. 46.
} 
extensive statements on "privatization" specifically in the context of the tripartite typology have taken place in the context of "protect": for instance, the obligation to protect the right to health includes the duty to ensure that privatization of the health sector does not constitute a threat to the availability, accessibility, acceptability, and quality of health facilities, goods, and services $;^{73}$ and the obligation to protect the right to work includes the duty to ensure that privatization measures do not undermine workers' rights. ${ }^{74}$

The biggest concern about the Committee concentrating on the obligation to protect in the context of privatization in this way is that such a focus suggests that privatization primarily involves a situation in which nonstate actors on their initiative act in a way which negatively impacts on rights without state involvement and that this is a situation that simply calls for state intervention to prevent and address such impacts. But in reality, as discussed above, privatization involves states (and state action/inaction) directly: privatization (in the sense of situations in which states formally mandate private sector actors to provide ESRrelated services) cannot occur without states making that possible, ${ }^{75}$ albeit that, as recognized earlier, they may not be acting autonomously in exercising a decision to implement such policies. ${ }^{76}$ As such, privatization aimed at the provision of ESR-related goods and services can - and in the author's view, should - be primarily viewed as one means by which the state chooses or acts to fulfill ESR. Such an understanding of privatization is particularly important when it comes to less developed economies in which states have not historically provided ESR-related goods and services to all (or most) right-holders in an efficient, effective way. In such contexts, state obligations cannot simply be viewed solely through a prism of concern with preserving existing enjoyment of ESR in the context of privatization processes; rather it is more appropriate to consider privatization as a mechanism chosen by states to do what the state is not in a position to do on its own - and to thereby advance enjoyment of ESR beyond existing levels. Indeed, such a view of privatization is consistent with that posited by actors

\footnotetext{
${ }^{73}$ CESCR GC No. 14, supra note 47, para. 35.

${ }^{74}$ CESCR GC No. 18 , supra note 47 , para. 25.

75 Indeed, the same can be argued in relation to informal provision by private actors, "implicit privatization," and privatization resulting from deregulation and liberalization as this takes place where states allow private actors to step in as providers.

${ }^{76}$ Where human rights-harming privatization is mandated by international financial institutions, this may have implications for the extraterritorial ESR obligations of member states of those organizations. The CESCR has emphasized that "States parties to the Covenant would be acting in violation of their obligations if they were to delegate powers to IMF or to other agencies and allowed such powers to be exercised without ensuring that they do not infringe on human rights." CESCR, Statement on Public Debt, Austerity Measures and the International Covenant on Economic, Social and Cultural Rights, supra note 39, para. 9. This would certainly extend to loan conditionality-induced privatization that violated ESR. For more on the obligations of states as members of intergovernmental organizations (including international financial institutions), see Principle 15 of the Maastricht Principles on Extraterritorial Obligations of States on Economic, Social and Cultural Rights, supra note 39.
} 
such as the World Bank who argue for privatization (albeit not in rights terms) on the basis that it will lower costs, improve infrastructure quantity and quality, and ensure better performance in relation to ESR-related goods and service delivery than if the state was left to its own devices. $^{77}$

The heavy focus on the obligation to protect rather than fulfill is an error on the Committee's part or - at the very least - involves a failure to appreciate a key element of the full picture of privatization. The obligation to fulfill better captures the state's decision to privatize in the first place, while the obligation to protect, with its focus on the protection of existing enjoyment of rights, centers on addressing problems in the context of a status quo of privatization. ${ }^{78}$ Considering privatization from the perspective of the obligation to fulfill will have implications for the identification and evaluation of state measures to be taken in the context of privatization. Admittedly, many of the steps required to ensure that the state complies with its obligation to fulfill ESR in the context of privatization may be very similar to those that have been outlined by the Committee and others in the context of the obligation to protect (e.g., ensuring the establishment and maintenance of regulatory and accountability mechanisms). However, an accurate appreciation of what is happening in privatization (and, indeed, pre- and post-privatization) situations from the perspective of the obligation to fulfill goes beyond that entailed by the obligation to protect; an "obligation to fulfill" approach will require the state to consider the compliance of privatization with ESR ab initio as a means to achieve the full realization of ESR, and will entail an engagement with the implications of privatization for the overall realization of ESR. In other words it will bring a far wider ESR obligations perspective to bear.

The Committee has expressly addressed the issue of privatization specifically in the context of a discussion of the obligation to fulfill ESR on only two occasions - in its 2000 General Comment No. 14 on the Right to the Highest Attainable Standard of Health and its

\footnotetext{
${ }^{77}$ For more (as well as a useful, accessible discussion of privatization in the context of public utilities relating to a range of ESR), see IOANNIS N. KESSIDES, REFORMING INFRASTRUCTURE: PRIVATIZATION, REGULATION, AND COMPETITION (2014).

${ }^{78}$ The obligation to respect also has implications for privatization where it interferes with existing enjoyment of ESR. Due to space constraints, this will not be a key focus of this paper. Furthermore, my view is that it is most important to conceptualize and interrogate privatization from the perspective of it being a positive measure taken by states in order to advance or enhance the delivery of ESR-related goods and services rather than as one for preventing state interference with existing enjoyment of those goods and services. Such an approach prioritizes engagement with the obligations to fulfill and protect. The Committee has referred to privatization in the context of the obligation to respect on only one occasion. See CESCR GC No. 21, supra note 47, esp. para. 50(b) (stating that states are obliged to "[r]espect and protect cultural heritage of all groups and communities," the Committee highlighted that "[p]articular attention should be paid to the adverse consequences of globalization, undue privatization of goods and services, and deregulation on the right to participate in cultural life.").
} 
2003 General Comment No. 15 on the Right to Water, respectively. In these instances, the Committee stressed that "[f]urther obligations include the provision of a public, private or mixed health insurance system which is affordable for all",79 and that states must ensure that water services, "whether privately or publicly provided, are affordable for all." ${ }^{80}$ However, even both of these General Comments included much more extensive discussions of privatization in their respective sections on the obligation to protect, stating that

obligations to protect include, inter alia, the duties of States to adopt legislation or to take other measures ensuring equal access to health care and health-related services provided by third parties; to ensure that privatization of the health sector does not constitute a threat to the availability, accessibility, acceptability and quality of health facilities, goods and services ${ }^{81}$

and, inter alia, that

[w] here water services (such as piped water networks, water tankers, access to rivers and wells) are operated or controlled by third parties, States parties must prevent them from compromising equal, affordable, and physical access to sufficient, safe and acceptable water. To prevent such abuses an effective regulatory system must be established, in conformity with the Covenant and this General Comment, which includes independent monitoring, genuine public participation and imposition of penalties for non-compliance. ${ }^{82}$

The Committee's error of emphasis is also frequently echoed in the scholarly literature. ${ }^{83}$ In the introduction to the leading collection in the area of privatization and human

\footnotetext{
${ }^{79}$ CESCR GC No. 14 , supra note 47 , para. 36.

${ }^{80}$ CESCR GC No. 15, supra note 47, para. 27. The Committee has made similar statements in other General Comments (see supra note 54) but not expressly in relation to the obligation to fulfill. See, e.g., CESCR GC No. 5, supra note 52, para. 11.

${ }^{81}$ CESCR GC No. 14, supra note 47, para. 35.

${ }^{82}$ CESCR GC No. 15, supra note 47, para. 24. See also id. para. 23.

${ }^{83}$ See, e.g., Felipe Gómez Isa, Globalisation, Privatisation and Human Rights, in PrIVATISATION AND HUMAN Rights IN THE AGE OF GLOBALISATION, supra note 7, at 9, 21 ("Dealing with privatisation, the obligation to protect is the most relevant one, since it requires states to prevent violations of economic, social and cultural rights by third parties. States have to ensure such rights are consistently protected once private actors take over the services."). See also Khulekani Moyo \& Sandra Liebenberg, The Privatization of Water Services: The Quest for Enhanced Human Rights Accountability, 37 HUM. RTS. Q. 691, 700 (2015) ("The state's duty to protect against violations of human rights by nonstate actors is often raised as an argument against the need to recognize and impose direct human rights duties on nonstate actors. The duty to protect enjoins the state to act positively to regulate, to prevent, and to remedy interferences by nonstate actors. In the context of the right to water, the state duty to protect would require the state to 'regulate private interactions to ensure that individuals are not arbitrarily deprived of the enjoyment of their right to water by other private individuals' and groups. As noted in
} 
rights, De Feyter and Gómez Isa cite approvingly a 1999 Paper by the UN Department of Economic and Social Affairs on Privatisation of Public Sector Activities,${ }^{84}$ describing the role of governments in the context of privatization as one that shifts from producing and delivering services to enabling and regulating. ${ }^{85}$ For De Feyter and Gómez Isa, "the principal question that arises is how the State can ensure compliance with its human rights obligations when its role in service delivery changes." however, when assessing states' compliance with their international obligations it is necessary to adopt an interrogatory (and, if necessary, critical) perspective on states' decisions about choice of service delivery. It is not simply a case of saying: "this is the model chosen, so now let's analyze state obligations in light of it." States adopt privatization models as part of their overall efforts to ultimately achieve full realization of ESR; to the extent that the obligation to protect arises, it does so after the initial decision to privatize has been taken - and that initial decision to privatize has ESR obligation implications as well.

De Feyter and Gómez Isa state that

the State cannot absolve itself of its international human rights obligations by delegating service delivery to private actors. The State remains responsible under human rights treaties even if the relevant service has been privatised. . . The actions that the State will need to undertake at the domestic level in order to avoid a breach of its human rights obligations do change, however. . . States will need to focus more after privatisation on the duty to provide protection against abuses by third parties, i.e., by the private actor who takes over responsibility for service provision. The State will only be able to provide protection, if it develops instruments for

the previous section [of the article], the involvement of the private sector in water delivery can give rise to a range of human rights concerns, making the state's protective duty essential.") (footnotes omitted) (quoting Matthew Craven, The International Covenant on Economic, Social, and Cultural Rights: A PERSPECTIVE ON ITS DEVElopMENT 112 (1995)). The work of Anton Kok writing in the context of the right to access to sufficient water under the South African Constitution provides an exception to the general failure to pay attention to the "fulfill" (and indeed "respect") obligation imposed by the right to water. See Anton Kok, Privatisation and the Right to Access to Water, in PRIVATISATION AND HuMAN Rights IN THE AGE OF GLOBALISATION, supra note 7, at 259, 282 ("[I]n appropriate circumstances a court may also find that the state has 'fulfilled' its duty to facilitate access to water by embarking on a well-directed privatisation programme."). Again in the context of the right to water, Danwood Chirwa provides a considerably more extensive discussion of the implications of the obligations to respect and fulfill human rights in the context of water privatization. See Danwood Mzikenge Chirwa, Privatisation of Water in Southern Africa: A Human Rights Perspective, 4 AFR. HUM. RTS. L.J. 218, 232-240 (2004).

${ }^{84}$ No full citation is given of this paper which is cited in Koen De Feyter \& Felipe Gómez Isa, Privatisation and Human Rights: An Overview, in PRIVATISATION AND Human Rights IN THE AgE of Globalisation, supra note 7 , at 1,1 .

${ }^{85} \mathrm{Id}$.

${ }^{86} I d$. at 2. 
overseeing the human rights impact of service delivery by the private actor, and for stepping in when human rights are abused. ${ }^{87}$

While De Feyter and Gómez Isa are certainly correct that "[u]pfront attention to the maintenance of regulatory capacity after privatisation is essential, ${ }^{, 88}$ this upfront attention should also be considered as part of the obligation to fulfill not just of the obligation to protect. Writing in the area of the right to education, Coomans and Hallo de Wolf note that "[i]n the area of privatisation, the general state duty to protect seems to be particularly relevant, because the state has to ensure that the right to education is fully enjoyed by learners once private bodies take care of educational services." 89

Another problem with focusing on the obligation to protect is that the obligation to protect has historically been addressed by the CESCR primarily in terms of preventing and addressing "interference" with ESR enjoyment by third parties. ${ }^{90}$ This has implications for

${ }^{87} I d$. at 3 . It should be noted that there are a number of major problems with the definition of the different
elements of the typology outlined by De Feyter and Gómez Isa here, with the view being expressed that the
obligation to respect relates to "rights for which people can self-provide" and the obligation to fulfill the right
"when people are unable to self-provide." This is not consistent with the Committee's delineation of these
obligations in any of its General Comments. Ironically, those authors' treatment of the obligation to protect as a
duty "to offer protection against abuse by third parties" is much closer to the Committee's approach to that obligation at the time at which they were writing.

${ }^{88} I d$. at 4.

${ }^{89}$ Fons Coomans \& Antenor Hallo de Wolf, Privatisation of Education and the Right to Education, in PRIVATISATION AND Human RightS IN THE AGE OF Globalisation, supra note 7, at 229, 239 (emphasis added). Interestingly from the perspective of the discussion in this article, Coomans and Hallo de Wolf proceed to state that "decisions to start privatisation in the sphere of education . . . should from a human rights perspective not increase inequality in society but rather contribute to a better realisation of the right to education for vulnerable groups." Id. at 240. They note further that "a state has an obligation to respect existing levels of protection, or put differently, to abstain from measures that would reduce the extent to which the right to education is guaranteed at a given moment." $I d$. This understanding of the obligations of the state would seem to bring in elements of the obligations to respect and fulfill ESR - but Coomans and Hallo de Wolf do not explore or even refer to those obligations in this section of the work, albeit that they do recognize towards the end of the same piece that if privatization policies endanger the requirements of the availability, accessibility, adaptability, and acceptability of education, "the state has a duty to abstain from these measures (in other words, the state has an obligation to respect the enjoyment of the right to education)." Id. at 253 .

${ }^{90}$ See, e.g., CESCR GC No. 12, supra note 63, para. 15 ("The obligation to protect requires measures by the State to ensure that enterprises or individuals do not deprive individuals of their access to adequate food."); CESCR GC No. 13, supra note 47, para. 47 ("The obligation to protect requires States parties to take measures that prevent third parties from interfering with the enjoyment of the right to education."); CESCR GC No. 14, supra note 47, para. 33 ("The obligation to protect requires States to take measures that prevent third parties from interfering with article 12 guarantees."); CESCR GC No. 15, supra note 47, para. 23 ("The obligation to protect requires State parties to prevent third parties from interfering in any way with the enjoyment of the right to water."); CESCR GC No. 16, supra note 53, para. 19 ("States parties' obligation to protect under article 3 of ICESCR includes, inter alia, the adoption of legislation to eliminate discrimination and to prevent third parties from interfering directly or indirectly with the enjoyment of this right.”); CESCR GC No. 17, supra note 47, para. 28 ("The obligation to protect requires States parties to take measures that prevent third parties from interfering with the moral and material interests of authors."); CESCR GC No. 18, supra note 47, para. 25 ("The obligation to protect requires States parties to take measures that prevent third parties from interfering with the enjoyment of the right to work."); CESCR GC No. 19, supra note 47, para. 45 ("The obligation to protect requires that State parties prevent third parties from interfering in any way with the enjoyment of the right to 
the Committee's capacity to deal with privatization-caused ESR harm that is not attributable to "interference." Even where the Committee has addressed situations where ESR-related delivery systems are operated or controlled by third parties, much of the focus in the Committee's obligation to protect jurisprudence in its General Comments, is essentially reactive, with states apparently being required to ensure that such parties do not compromise existing enjoyment of, or access to, ESR-related goods and services rather than being required to consider in detail the rights compliance of the permitting of such control (and the determination of appropriate parameters of such control) in the first place. In instances in which the Committee makes clear that states must ensure that privatization does not "constitute a threat to," interfere with or undermine the availability, accessibility, acceptability, and quality of ESR-related facilities, goods, and services,${ }^{91}$ the language used by the Committee seems to suggest that such availability, accessibility, acceptability, and quality of such facilities, goods, and services is the default position with privatization potentially operating against this. While this may just be a question of a poor choice of language, the effect of its use is that there is a failure to engage with privatization as a positive state choice involving the enabling (and in some instances the incentivization) of

social security."); CESCR GC No. 21, supra note 47, para. 48 ("The obligation to protect requires States parties to take steps to prevent third parties from interfering in the right to take part in cultural life."); CESCR GC No. 22, supra note 51, para. 59 ("The obligation to protect requires States to take measures to prevent third parties from directly or indirectly interfering with the enjoyment of the right to sexual and reproductive health."); CESCR GC No. 23, supra note 47, para. 42 ("The obligation to protect requires States parties to take measures to ensure that third parties, such as private sector employers and enterprises, do not interfere with the enjoyment of the right to just and favourable conditions of work and comply with their obligations.").

${ }^{91}$ See, e.g., CESCR GC No. 12, supra note 63, para. 15 ("The obligation to protect requires measures by the State to ensure that enterprises or individuals do not deprive individuals of their access to adequate food."); CESCR GC No. 13, supra note 47, para. 50 ("[A] State must . . . protect the accessibility of education by ensuring that third parties, including parents and employers, do not stop girls from going to school."); CESCR GC No. 14, supra note 47, para. 35 ("Obligations to protect include, inter alia, the duties of States . . to ensure that privatization of the health sector does not constitute a threat to the availability, accessibility, acceptability and quality of health facilities, goods and services."); CESCR GC No. 15, supra note 47, para. 24 ("Where water services (such as piped water networks, water tankers, access to rivers and wells) are operated or controlled by third parties, States parties must prevent them from compromising equal, affordable, and physical access to sufficient, safe and acceptable water."); CESCR GC No. 18, supra note 47, para. 25 (“Obligations to protect the right to work include, inter alia, the duties of States parties to adopt legislation or to take other measures ensuring equal access to work and training and to ensure that privatization measures do not undermine workers' rights."); CESCR GC No. 19, supra note 47, para. 46 ("Where social security schemes, whether contributory or non-contributory, are operated or controlled by third parties, States parties retain the responsibility of administering the national social security system and ensuring that private actors do not compromise equal, adequate, affordable, and accessible social security."); CESCR GC No. 22, supra note 51, para. 42 ("The duty to protect requires States to put in place and implement laws and policies prohibiting conduct by third parties that causes harm to physical and mental integrity or undermines the full enjoyment of the right to sexual and reproductive health, including the conduct of private health-care facilities ... This includes the prohibition of violence and discriminatory practices, such as the exclusion of particular individuals or groups from the provision of sexual and reproductive health services."); id. para. 60 ("States must effectively monitor and regulate specific sectors, such as private health-care providers . . . to ensure that they do not undermine or violate enjoyment by individuals of the right to sexual and reproductive health."). 
third parties, as opposed to something that arises organically and in relation to which the state's chief role is reactive. This approach would be unproblematic on occasions in which privatization is also dealt with elsewhere in its discussion of the tripartite typology (as was the case in the Committee's General Comment No. 14 on the Right to the Highest Attainable Standard of Health discussed above) $;{ }^{92}$ where this does not occur, there is a clear gap in terms of the decision-making and processes at a key stage of privatization. This is thus an example of a substantive way in which the (mis)characterization of privatization in the context of the typology operates to reduce the scope of human rights protection in the context of privatization.

It is not accurate to say, as Murthy does, that "[a]n inverse relationship exists between the protect and fulfill prongs: The more a state delegates its responsibilities to fulfill to a nonstate actor, the greater its duty to protect", ${ }^{93}$ while the state may delegate its responsibilities (in the sense of its operational responsibilities) and increase the scope of activity required of it in terms of the obligation to protect, its obligation to fulfill in terms of IHRL remains as extensive as before. The use of privatization does not make the obligation to fulfill merely "default" - applying only where there is no nonstate actor involvement. Rather, the obligation to fulfill is directly implicated in terms of the state's decision to privatize in the first place, the form that any such privatization arrangement takes, and in assessing the success of that arrangement(s) in terms of advancing or undermining the overall realization of ESR. These stages or loci of decision-making are not captured effectively where the key prism for the Committee's analysis is the obligation to protect, given the Committee's historic emphasis on "interference" rather than the wide range of ways in which nonstate actors can affect ESRboth positively and negatively - in a privatization context. While the obligation to fulfill underpins and is relevant at all times during privatization processes, the obligation to protect (as traditionally conceptualized by the Committee and reflected in the work of Shue, Eide, and others which served as the basis of the Committee's approach) $)^{94}$ primarily comes into

\footnotetext{
${ }_{92}$ See discussion supra in the context of the General Comments on the right to health and water.

${ }^{93}$ Sharmila L. Murthy, The Human Rights(s) to Water and Sanitation: History, Meaning, and the Controversy over Privatization, 31 BERKELEY J. INT'L LAW 89, 142 (2013). It should be noted however that Murthy makes clear elsewhere in the piece that "states cannot sidestep their responsibilities by involving the private sector, but instead retain the duties to protect, respect, and fulfill the right." Id. at 147.

${ }^{94}$ See Henry Shue, The Interdependence of Duties, in THE RIGHT TO FOOD 83 (Philip Alston \& Katarina Tomaševski eds., 1984) (emphasizing the obligation "to protect from deprivation"); UN Sub-Commission on Prevention of Discrimination and Protection of Minorities, The Realization of Economic, Social and Cultural Rights: Report Updating the Study on the Right to Food Prepared by Mr. Asbjørn Eide, para. 9, UN Doc. E/CN.4/Sub.2/1998/9 (June 29, 1998) (expressing concern that "third parties are likely to interfere negatively with the possibilities that individuals or groups otherwise might have had to solve their own needs" and that therefore "State obligations require active protection against other, more assertive or aggressive
} 
play in an ESR context where actors that have been mandated to carry out functions related to ESR goods and service delivery (and as explained earlier this article is only looking at situations in which there has been such formal mandating) operate in such a way as to threaten or damage existing rights enjoyment (for instance, where private entities hike tariffs beyond the level of affordability resulting in an interference with pre-existing levels of rights enjoyment). It is not engaged when such actors fail to advance enjoyment of ESR (which would relate to the obligation to fulfill and the overarching obligation of progressive realization under Article 2(1) ICESCR). If we consider a situation in which privatization does not interfere with (aka reduce/negatively impact on) the enjoyment of ESR that pertained prior to privatization, then that would seem to be unobjectionable from the perspective of the obligation to protect; the fact that such privatization did not in fact result in the state advancing in terms of ESR realization would not be an issue. However, from the perspective of the obligation to fulfill, where the emphasis is on positive measures directed towards the goal of full realization, it is strongly questionable whether such maintenance of the status quo would be sufficient. Certainly it would not be in terms of the Article 2(1) ICESCR obligation of progressive realization unless the state could point to other, complementary measures ensuring that the state was moving towards the goal of full realization of ESR "as expeditiously and effectively as possible." 95 When privatization is considered from the perspective of the obligation to fulfill, the Committee would be expected to consider such activity in light of the constituent elements of the obligation to fulfill: the duties to facilitate, promote, and provide. Questions to be asked about privatization pre, during and post the privatization process would include: would/does the privatization arrangement in question enable and assist individuals and communities to enjoy the ESR in question (i.e., would/does it facilitate that ESR)? Would/does privatization result in increased education about or public awareness of the ESR in question (i.e., would/does it promote that ESR)? Would/does privatization result in provision of the relevant ESR to those who cannot realize that right

\footnotetext{
subjects - more powerful economic interests, such as protection against fraud, against unethical behaviour in trade and contractual relations, against the marketing and dumping of hazardous or dangerous products"). For more on the role played by Shue and Eide's work in relation to the development of the typology, as well as other conceptions of the typology, see IDA ElisabeTH KOCH, Human RIGHTS AS Indivisible RIGHTS: THE PRotection of SOCIO-ECONOMIC DEMANDS UNDER THE EUROPEAN CONVENTION ON HuMAN RightS 14-17 (2009).

${ }^{95}$ CESCR GC No. 3, supra note 6, para. 9. I am not suggesting that progressive realization in terms of Article 2(1) directly corresponds to the obligation to fulfill. However, there is undoubtedly a close relationship between the two as conceptualized by the Committee, and the obligation to fulfill plays an important role in terms of crystallizing state duties in the context of state efforts to ensure increased rights enjoyment as envisaged by the obligation of progressive realization in Article 2(1).
} 
themselves by the means at their disposal (i.e., would/does it provide that ESR)? ${ }^{96}$ These questions would be posed so as to assess the extent to which the state conceptualizes and employs privatization so as to advance ESR enjoyment, in light of the ultimate goal of ICESCR - the full realization of ESR.

\section{B. A Similar Picture from (Sometimes) a Different Angle? The Work of the Other UN Treaty-}

\section{Monitoring Bodies on ESR and Privatization}

Moving beyond the CESCR to look at other treaty-monitoring bodies with an ESR mandate, it is evident that even the relatively limited engagement of CESCR with privatization is more developed than that of the four UN Committees assessing ESR implementation from the perspectives of race, disability, migrant workers, and gender equality. None of these bodies have progressed further than the CESCR in their General Comments/Recommendations and Day of General Discussions/Thematic Discussion recommendations in terms of addressing the forms, processes, outputs, and outcomes of privatization - or in detailing the specific negative rights impacts of such. ${ }^{97}$

The Committee on the Elimination of All Forms of Racial Discrimination has made clear that private actors can have a role in creating and exacerbating discrimination in terms of ESR enjoyment, ${ }^{98}$ in particular education, ${ }^{99}$ without however engaging with privatization to any meaningful extent. The Committee on the Rights of Persons with Disabilities has also focused on the impact of private actors in relation to education-specifically inclusive

\footnotetext{
${ }^{96}$ These questions are based on the language employed by the Committee in delineating the obligation to fulfill in a range of its General Comments. The typology was introduced in General Comment No. 12. It was only in General Comment No. 14, that the constituent element of the duty to "promote" was added to the duties to facilitate and provide outlined in General Comments Nos. 12 and 13.

${ }^{97}$ Hallo de Wolf has noted that "[ $\mathrm{t}$ ] he UN's human rights treaty bodies approach has in general acknowledged privatisation as a measure that States may adopt, but which may sometimes have negative effects on the enjoyment of human rights. However, it is not always clear on which basis some of the treaty bodies come to the conclusion that privatization may have detrimental consequences for human rights, or under which particular conditions this may happen." HALLO DE WOLF, supra note 57, at 394-95. While Hallo de Wolf made this point in 2012, it remains true in 2016. Analysis in this section focuses solely on General Comments/Recommendations and Days of General Discussion on the basis that these are the key statements of these bodies on ESR and privatization.

${ }^{98}$ See Committee on the Elimination of All Forms of Racial Discrimination (CERD), General Recommendation XXIX on Article 1, Paragraph 1, of the Convention (Descent), ch. 7, UN Doc. HRI/GEN/1/Rev.9 (Vol. II) at 296 (2002) [hereinafter CERD GR XXIX]; CERD, General Recommendation XX on Article 5 of the Convention, para. 5, UN Doc. HRI/GEN/1/Rev.9 (Vol. II) at 281 (1996) (highlighting concern about the impact of "private institutions" in influencing "the exercise of rights or the availability of opportunities"). More generally, see CERD, General Recommendation XIX on Article 3 of the Convention, paras. 3-4, UN Doc. HRI/GEN/1/Rev.9 (Vol. II) at 281 (1995).

${ }^{99}$ See CERD GR XXIX, supra note 98, ch. 8; CERD, General Recommendation No. 34: Racial Discrimination Against People of African Descent, para. 62, UN Doc. CERD/C/GC/34 (Oct. 3, 2011).
} 
education - stating that "States parties must ensure that persons with disabilities are able to access education in both public and private academic institutions on an equal basis with others." 100 In doing so, that body emphasized that the obligation to protect "requires taking measures that prevent third parties from interfering with the enjoyment of the right, for example ... private institutions refusing to enroll persons with disabilities on the basis of their impairment," but also highlighted that the obligation to fulfill "requires taking measures that enable and assist persons with disabilities to enjoy the right to education, for example, ensuring that educational institutions are accessible and that education systems are adapted appropriately with resources and services." ${ }^{101}$ This presumably applies to private education systems and thus constitutes an implicit engagement with privatization. The Committee's focus on ensuring accessibility of ESR-related goods and services (including those that are privatized) is a repeated theme in its work, with it making clear that

[t]he focus is no longer on legal personality and the public or private nature of those who own buildings, transport infrastructure, vehicles, information and communication, and services. As long as goods, products and services are open or provided to the public, they must be accessible to all, regardless of whether they are owned and/or provided by a public authority or a private enterprise. . . . This approach stems from the prohibition against discrimination; denial of access should be considered to constitute a discriminatory act, regardless of whether the perpetrator is a public or private entity. ${ }^{102}$

The Committee on Migrant Workers has also addressed the risks posed to migrant workers and their families from privatization, highlighting the "particular difficulties" posed by privately run migrant detention centers in terms of monitoring and emphasizing that "administrative detention of migrant workers should, as a rule, take place in public establishments" and that "States parties cannot absolve themselves of their human rights obligations by contracting out the detention of persons to private commercial enterprises." It has not, however, engaged with the tripartite typology in this context.

\footnotetext{
${ }^{100}$ Committee on the Rights of Persons with Disabilities (CRPD), General Comment No. 4 on the Right to Inclusive Education, para. 24, UN Doc. CRPD/C/GC/4 (Nov. 25, 2016).

${ }^{101} I d$. para. 39.

${ }^{102}$ CRPD, General Comment No. 2: Article 9: Accessibility, para. 13, UN Doc. CRPD/C/GC/2 (May 22, 2014).

${ }^{103}$ Committee on Migrant Workers, General Comment No. 2 on the Rights of Migrant Workers in an Irregular Situation and Members of Their Families, para. 39, UN Doc. CMW/C/GC/2 (Aug. 28, 2013). See also the Committee's statements with regard to violence experienced by migrant workers in an irregular situation at the hands of private actors, id. para. 21.
} 
The Committee on the Elimination of All Forms of Discrimination Against Women (CEDAW) has made only relatively limited references to privatization, despite the reference in Article 2(e) of the Convention on the Elimination of All Forms of Discrimination Against Women to states parties' obligation "to take all appropriate measures to eliminate discrimination against women by any person, organization or enterprise." ${ }^{\text {"104 }}$ The Committee has used the word "privatization" only once explicitly in its General Recommendations: in its General Recommendation No. 34 on the Rights of Rural Women, it stated that states parties "should address the negative and differential impacts of economic policies, including . . . privatization ... on the lives of rural women and the fulfilment of their rights. ${ }^{[105]}$ Similarly, development partners should also ensure that their development assistance policies focus on the specific needs of rural women."106

Positively, from a tripartite typology analysis perspective, CEDAW clearly views privatization as having implications for state obligations to respect, protect, and fulfill; in the context of its analysis of the topic of women and health in its General Recommendation No. 24, CEDAW has stated that "[ $\mathrm{t}]$ he obligation to respect rights requires States parties to refrain from obstructing action taken by women in pursuit of their health goals." ${ }^{107}$ As part of this: "States parties should report on how public and private health-care providers meet their duties to respect women's rights to have access to health care." 108 This is however a rather confused statement - under IHRL, the obligation to respect adheres to the state, not to private healthcare providers - and if it is to be read as consistent with the understanding of that obligation, then "their duties" must be understood to refer to states, rather than providers. While privatization is not explicitly mentioned in the context of the obligation to protect, the Committee makes clear its view that that duty requires states "to take action to prevent and impose sanctions for violations of rights by private persons and organizations."109 The most detailed statement by CEDAW in relation to privatization occurred in the context of its discussion of the obligation to fulfill in the same General Recommendation, where it expressed its concern

\footnotetext{
${ }^{104}$ Dec. $18,1979,1249$ U.N.T.S. 13.

${ }^{105}$ It should be noted that "fulfilment" in this instance appears to denote "realization" rather than the obligation to fulfill.

${ }^{106}$ CEDAW, General Recommendation No. 34 (2016) on the Rights of Rural Women, para. 11, UN Doc. CEDAW/C/GC/34 (Mar. 7, 2016).

${ }^{107}$ CEDAW, General Recommendation No. 24: Article 12 of the Convention (Women and Health), para. 14, UN Doc. A/54/38/Rev.1 (1999).

${ }^{108} I d$.

${ }^{109} I d$. para. 15 .
} 
about the evidence that States are relinquishing these obligations as they transfer State health functions to private agencies. States and parties cannot absolve themselves of responsibility in these areas by delegating or transferring these powers to private sector agencies. States parties should therefore report on what they have done to organize governmental processes and all structures through which public power is exercised to promote and protect women's health. They should include information on positive measures taken to curb violations of women's rights by third parties and to protect their health and the measures they have taken to ensure the provision of such services. ${ }^{110}$

Despite this, when it came to delineating the core obligations of states parties under Article 2 of the Convention on the Elimination of All Forms of Discrimination Against Women in its General Recommendation No. 28 on this topic, obligations vis-à-vis preventing discrimination by private actors were only addressed in relation to the obligation to protect. ${ }^{111}$ Elsewhere in the General Recommendation, CEDAW highlighted the need for states to prevent and address discrimination in both the private and public spheres in such a way as to make it evident it applied to situations of privatization. ${ }^{112}$ Furthermore-and again not in the context of its discussion of the typology - in outlining the state's "due diligence" obligation (generally associated with the obligation to protect) ${ }^{113}$ which operates to prevent discrimination by private actors being attributed to the state, CEDAW highlighted that the "appropriate measures that States parties are obliged to take include the regulation of the activities of private actors with regard to education, employment and health policies and practices, working conditions and work standards, and other areas in which private actors provide services or facilities, such as banking and housing." 114 Again this can be understood as a UN treaty-monitoring body outlining obligation to protect-related measures in the context of status quo privatization.

\footnotetext{
${ }^{110} I d$. para. 17.

${ }^{111}$ CEDAW, General Recommendation No. 28 on the Core Obligations of States Parties Under Article 2 of the Convention on the Elimination of All Forms of Discrimination Against Women, para. 9, UN Doc. CEDAW/C/GC/28 (Dec. 16, 2010) [hereinafter CEDAW GR No. 28].

${ }_{112}^{1} I$. paras. $10,25,34$.

${ }^{113}$ See Nolan, supra note 70 . For a recent example of the connection between due diligence and the obligation to protect being made by CEDAW, see CEDAW, General Recommendation No. 30 on Women in Conflict Prevention, Conflict and Post-conflict Situations, para. 15, UN Doc. CEDAW/C/GC/30 (Nov. 1, 2013). This connection is also made by the CESCR in its General Comment No. 24. See CESCR GC No. 24, supra note 1, paras. 15-16, 32-33.

${ }^{114}$ CEDAW GR No. 28, supra note 111, para. 13.
} 
Ultimately, what emerges from the practice of these Committees, as with the CESCR, is an underlying concern with the impact of private actors but with limited consideration (with the notable exception of CEDAW General Recommendation No. 24) being given to how privatization engages with different elements of the tripartite typology.

Beyond the CESCR, the UN treaty-monitoring body that has so far focused on the issue of privatization to the greatest extent is the Committee on the Rights of the Child (ComRC). Here we see a very different story involving UN treaty body engagement with these issues than the one we have so far been telling. The ComRC has made it clear that private actors and privatization arrangements can play a role in "the provision and management of services such as clean water, sanitation, education, transport, health, alternative care, energy, security and detention facilities that are critical to the enjoyment of children's rights." 115 However, it has also recognized that the process of privatization of services can have a serious impact on the recognition and realization of children's rights ${ }^{116}$ and has highlighted standards that privatization processes must meet.

The Committee's concern with "the high relevance" of the "assumption by nongovernmental organizations or businesses of traditional State functions" to its work resulted in a Day of General Discussion (DGD) in 2002. ${ }^{117}$ The aims of the day placed the "direct and indirect" impacts of privatization arrangements on the "full realization" 118 of the rights of the child front and center, with participants agreeing that Article 4 of the Convention on the Rights of the Child (CRC) - the umbrella obligation of the CRC which requires states to "undertake all appropriate legislative, administrative, and other measures for the implementation of the rights" — was a "fundamental provision to be considered by States parties when dealing with non-State service providers." ${ }^{\prime 20}$ A stated goal of the DGD was the specification of obligations of states in the context of privatization "in terms of positive obligations, ensuring non-discrimination with regard to access, equitable and affordable access, especially for marginalized groups, as well as assuring quality and sustainability of

\footnotetext{
115 ComRC, General Comment No. 16 on State Obligations Regarding the Impact of the Business Sector on Children's Rights, para. 33, UN Doc. CRC/C/GC/16 (Apr. 17, 2013) [hereinafter ComRC GC No. 16].

${ }^{116}$ ComRC, General Comment No. 5: General Measures of Implementation of the Convention on the Rights of the Child, para. 42, UN Doc. CRC/GC/2003/5 (Nov. 27, 2003) [hereinafter ComRC GC No. 5].

${ }^{117}$ ComRC, The Private Sector as Service Provider and its Role in Implementing Child Rights, contained in ComRC, Report on the Thirty-first Session, paras. 630-53, 633, UN Doc. CRC/C/121 (Dec. 11, 2002) [hereinafter ComRC DGD].

${ }_{118}$ Id. para. 634 (emphasis added).

${ }^{119}$ CRC, supra note 23, art. 4.

${ }^{120}$ ComRC DGD, supra note 117, para. 645.
} 
service provision." ${ }^{121}$ Furthermore, obligations "with respect to the regulation and monitoring of the activities of the private sector, including the adoption of a rights-based approach to service provision, [would] be specified." "22 The Chair of the Committee at the time highlighted in particular the "growing trend of privatization, including in the provision of services addressing basic needs, including health, education and water" and noted that this gave rise to "a lot of questions which are difficult and complex and had not yet been fully addressed. In fact, these questions had never been addressed by a human rights treaty body before" ${ }^{\prime 123}$ (a statement which could be taken as a less-than-subtle sideswipe at the CESCR). Selected elements of the extensive recommendations to states emanating from the DGD were eventually incorporated into the Committee's General Comments No. 5 and No. 16, one and twelve years later, respectively. ${ }^{124}$

The Committee's General Comment No. 5 on General Measures of Implementation of the Convention on the Rights of the Child emphasized that "enabling the private sector to provide services, run institutions and so on does not in any way lessen the State's obligation to ensure for all children within its jurisdiction the full recognition and realization of all rights in the Convention." 125 According to the Committee, "non-State service providers operate in accordance with [the CRC's] provisions, thus creating indirect obligations on such actors."126 These are not obligations that are enforceable against such private actors under IHRL as it stands. ${ }^{127}$ That is not the case, however, with regard to the state's obligations in the context of privatization, where states "have a legal obligation to respect and ensure the rights of children as stipulated in the Convention, which includes the obligation to ensure that non-State service

\footnotetext{
${ }^{121}$ Id. para. 634.

${ }^{122}$ Id. Another goal of the session was to "identify and strengthen awareness of the responsibilities and obligations of private service providers, both for profit and not for profit, under the Convention" on the Rights of the Child, id. This will not be addressed here.

${ }^{123}$ Id. para. 640.

${ }^{124}$ The DGD also contained recommendations to nonstate service providers and general recommendations, $i d$. para. 653. These will not be addressed here.

${ }^{125}$ ComRC GC No. 5, supra note 116, para. 44 ("Article 3(1) establishes that the best interests of the child shall be a primary consideration in all actions concerning children, whether undertaken by public or private bodies. Article 3(3) requires the establishment of appropriate standards by competent bodies (bodies with the appropriate legal competence), in particular, in the areas of health, and with regard to the number and suitability of staff. This requires rigorous inspection to ensure compliance with the Convention. The Committee proposes that there should be a permanent monitoring mechanism or process aimed at ensuring that all State and nonState service providers respect the Convention.").

${ }^{126} I d$. para. 43. It should be noted that it is unclear how the imposition of a duty on the state to ensure that nonstate actors act in accordance with the CRC's provisions gives rise to "indirect obligations" on those nonstate actors.

${ }^{127}$ This is consistent with other duties and responsibilities of nonstate actors identified in terms of the CRC, for instance those of parents and legal guardians of the child. See, e.g., CRC, supra note 23, arts. 5, 18, 27).
} 
providers operate in accordance with its provisions." 128 The same General Comment proposes that there should be a permanent monitoring mechanism or process aimed at ensuring that all nonstate service providers respect the Convention. ${ }^{129}$

The Committee on the Rights of the Child provided further insights into the relationship between the CRC and privatization in its 2013 General Comment No. 16 on State Obligations Regarding the Impact of the Business Sector on Children's Rights. ${ }^{130}$ Again highlighting the trend towards privatization, ${ }^{131}$ the Committee stated that "States must ensure that the best interests of the child are central to the development of legislation and policies that shape business activities and operations, such as those relating to . . privatization."132 Furthermore, while stressing that the Committee does not prescribe the form of delivery of ESR-related (and other rights-related) services, it emphasized that states are not exempted from their obligations under the CRC when they outsource or privatize services that impact on the fulfillment of children's rights. Engaging expressly with the tripartite typology, the Committee reiterated that states are not relieved of their obligations under the Convention and its protocols when their functions are delegated or outsourced. ${ }^{133}$ In doing so, it highlighted that the obligation to respect "means that States should not directly or indirectly facilitate, aid and abet any infringement of children's rights"; furthermore, states have the obligation to ensure that all actors respect children's rights, including in the context of business activities and operations. ${ }^{134}$

Perhaps unsurprisingly given what we have seen in terms of the other treatymonitoring bodies' practice (but disappointingly from the perspective of the tripartite typology-related arguments being made in this article and from the relatively expansive nature of the comments we have seen it has been willing to make), the Committee emphasized that the obligation to protect is of "primary importance" when considering states' obligations with regards to the business sector (which admittedly go beyond privatization) and made clear that it requires states to take all "necessary, appropriate and reasonable measures to prevent business enterprises from causing or contributing to abuses of children's

\footnotetext{
${ }^{128}$ ComRC GC No. 5, supra note 116, para. 43.

${ }^{129} I d$. para. 45.

${ }^{130}$ ComRC GC No. 16, supra note 115.

${ }^{131} I d$. para. 1.

${ }^{132}$ Id. para. 15. For more on this point, see ComRC, General Comment No. 14 on the Right of the Child to Have His or Her Best Interests Taken as a Primary Consideration, paras. 1, 12, UN Doc. CRC/C/GC/14 (May 29, 2013) [hereinafter ComRC GC No. 14].

${ }^{133}$ ComRC GC No. 16, supra note 115, para. 25.

${ }^{134}$ Id. para. 26.
} 
rights." 135 According to the Committee, such measures can encompass "the passing of law and regulation, their monitoring and enforcement, and policy adoption that frame how business enterprises can impact on children's rights."136 The Committee's statements in relation to the obligation to protect did not refer to privatization specifically and, when delineating what specific measures this level of obligation requires, it focused very much on the creation of an effective legal framework of a regulatory nature. ${ }^{137}$

When looking at state obligations in the context of the provision of services for children's rights, ${ }^{138}$ the Committee specified that states are required to adopt specific measures that take account of the involvement of the private sector in service delivery to ensure the rights enumerated in the Convention are not compromised. ${ }^{139}$ This includes an obligation "to set standards in conformity with the [CRC] and closely monitor them" requirement that can be viewed as relating to both protect and fulfill. The Committee also made clear that states must ensure that "such provision does not threaten children's access to services on the basis of discriminatory criteria, especially under the principle of protection from discrimination." ${ }^{141}$ In terms of remedies for violations of rights in the context of privatization and more broadly ("for all service sectors"), children must be provided with access to an independent monitoring body, complaints mechanisms, and, where relevant, to recourse to the courts. Building on its earlier General Comment No. 5, the Committee recommended that "there should be a permanent monitoring mechanism or process aimed at ensuring that all non-State service providers have in place and apply policies, programmes and procedures which are in compliance with the Convention." 142

While these are the key instances in which the Committee has expressed its views on privatization, it has also touched on the issue in its work on early childhood ${ }^{143}$ (where it devoted a section of a General Comment to "the private sector as service provider"), juvenile

\footnotetext{
${ }^{135}$ Id. para. 28.

${ }^{136} \mathrm{Id}$.

${ }^{137}$ Id. para. 32.

${ }^{138}$ While this discussion followed the section of the General Comment on the obligation to fulfill, it could be understood as relating to that obligation, given the Committee's earlier emphasis that the "obligation to fulfil requires States to take positive action to facilitate, promote and provide for the enjoyment of children's rights," $i d$. para. 29 (emphasis added), and the reference at the end of paragraph 33 referring to the "fulfilment" of children's rights. I would be reluctant to assert that the Committee was deliberately linking this section to the obligation to fulfill only given that the measures outlined in it clearly relate to the obligations to respect and protect also.

${ }^{139} I d$. para. 34.

${ }^{140} I d$.

${ }^{141} I d$.

${ }^{142} I d$.

143 ComRC, General Comment No. 7: Implementing Child Rights in Early Childhood, UN Doc. CRC/C/GC/7/Rev.1 (Sept. 20, 2006), esp. para. 32 on "the private sector."
} 
justice, ${ }^{144}$ health (where the Committee included a section on "non-state service providers and other non-state actors" in the relevant General Comment), ${ }^{145}$ and budgets (where the Committee made several references to outsourcing, calling on states to ensure that resources and capacity are in place to conduct monitoring and budget analyses of services outsourced to the private sector). ${ }^{146}$ In its General Comment No. 14 on the Right of the Child to Have His or Her Best Interests Taken as a Primary Consideration it made clear that "private social welfare institutions" for the purposes of the application of the best interests principles set out in Article 3(1), include "private sector organizations - either for-profit or non-profit - which play a role in the provision of services that are critical to children's enjoyment of their rights, and which act on behalf of or alongside Government services as an alternative."147

What emerges from this analysis is a Committee that has seriously considered the way in which privatization raises concerns from the perspective of a range of different obligations and recognizes that privatization is not simply a question of the control of independent third parties that interfere with children's rights enjoyment on their own initiative but relates directly to state choices about the full implementation of children's rights. While the Committee did not expressly link privatization with any of the levels of the typology, it made clear through its general language when outlining each element of the typology that privatization could fall under any or all of them rather than narrowly explicitly or implicitly restricting consideration of privatization-related issues to the obligation to protect. This holistic understanding of the ESR implications of privatization is a significant advance on the narrow, "obligation to protect" focused (fixated?) approach historically adopted by CESCR and the even looser analysis of the other bodies that we have discussed. The approach of the ComRC demonstrates the truth of Liebenberg's observation that a complex matrix of duties are applicable in a state-undertaken privatization program and that, on that basis, the conception of the legal framework under IHRL cannot be limited to just one set of duties. ${ }^{148}$ In contrast, the CESCR's primary focus on the state's duties as indirectly horizontal in terms of the obligation to protect at the expense of the state's direct vertical obligations in terms of

\footnotetext{
${ }^{144}$ ComRC, General Comment No. 10: Children's Rights in Juvenile Justice, para. 20, UN Doc. CRC/C/GC/10 (Apr. 25, 2007).

${ }^{145}$ ComRC, General Comment No. 15 on the Right of the Child to the Enjoyment of the Highest Attainable Standard of Health, paras. 79-85, UN Doc. CRC/C/GC/15 (Apr. 17, 2013).

${ }^{146}$ ComRC, General Comment No. 19 on Public Budgeting for the Realization of Children's Rights, para. 100, UN Doc. CRC/C/GC/19 (July 20, 2016). See also id. para. 85 on outsourcing, budgets, and child rights.

${ }^{147}$ ComRC GC No. 14, supra note 132, para. 26. See also ComRC GC No. 5, supra note 116, para. 44 (quoted supra note 125).

${ }^{148}$ E-mail from Sandra Liebenberg, H.F. Oppenheimer Chair in Human Rights Law, Department of Public Law, Stellenbosch University, to author (Oct. 20, 2016) (on file with author).
} 
the obligation to fulfill means that it fails to appreciate the multiple ways in which state obligations are engaged at different stages and in different contexts of privatization.

\section{A NEW DAWN FOR PRIVATIZATION AND ESR?}

Much of this article has been highly critical of the CESCR's performance with regard to addressing ESR-related measures and harms related to privatization in terms of the tripartite typology. While privatization is a complex, multifaceted phenomenon, the Committee's failure to adequately conceptualize it in terms of the different elements of the typology (and indeed ESR obligations more broadly) severely restricts the ability of state actors, ESR advocates and others to ensure that privatization is ESR-compliant. It is thus fitting to conclude by considering the Committee's most recent and extensive discussion of privatization, which takes place in the General Comment No. 24, issued in June 2017, on State Obligations Under the International Covenant on Economic, Social and Cultural Rights in the Context of Business Activities. ${ }^{149}$ Does this recent intervention mark a turning point in the Committee's approach to the issue?

The ground may be shifting to some extent so far as the tripartite structure and the Committee's approach to privatization is concerned. From an obligations perspective, it is striking that the Committee provides an understanding of the obligation to protect that is quite different to that in its earlier work, and much broader:

The obligation to protect means that States Parties must effectively prevent the infringements of economic, social and cultural rights in the context of business activities. This requires that States Parties adopt legislative, administrative, educational, as well as other appropriate measures, to ensure effective protection against Covenant rights violations linked to business activities; and that they provide victims of such corporate abuses with access to effective remedies. ${ }^{150}$

By moving away from the traditional understanding of the obligation to protect that focuses on third party interference with ESR enjoyment to extend it to a duty "to prevent the infringements of economic, social and cultural rights in the context of business activities," the Committee would appear to have extended the scope of state obligation envisaged under the

\footnotetext{
${ }^{149}$ CESCR GC No. 24, supra note 1.

${ }^{150} I d$. para. 14. An equally expansive approach to the obligation to protect is adopted in the context of the discussion of extraterritorial obligations. See id. para. 30.
} 
obligation to protect discussed above. The breadth of the obligation to protect is also made clear in the Committee's statement that states would violate their duty to protect Covenant rights "by failing to prevent or to counter conduct by businesses that leads to such rights being abused, or that has the foreseeable effect of leading to such rights being abused for instance." $" 151$

There is evidence elsewhere in the obligation to protect section of the General Comment that the Committee has chosen to use that obligation as a catch-all for all state duties related to nonstate actors, even where the actions outlined by the Committee could be viewed as correlated to the obligation to fulfill as well, and perhaps even more suitably linked to that duty. One example of this is the Committee's statement that "States thus retain at all times the obligation to regulate private actors to ensure that the services they provide are accessible to all, are adequate, are regularly assessed in order to meet the changing needs of the public and are adapted to those needs." 152 Another is the Committee's view of the obligation to protect as entailing more "direct regulation and intervention"153 in terms of which states are urged to consider measures such as

restricting marketing and advertising of certain goods and services in order to protect public health ... combating gender role stereotyping and discrimination; exercising rent control in the private housing market as required for the protection of everyone's right to adequate housing; establishing minimum wage [sic] consistent with a living wage and a fair remuneration; regulating other business activities concerning the Covenant rights to education, employment, and reproductive health, in order to effectively combat gender discrimination; and gradually eliminating informal or "non-standard" (i.e., precarious) forms of employment, which often result in denying the workers concerned the protection of labour laws and social security. ${ }^{154}$

These measures are also pertinent from the perspective of the obligation to fulfill ESR — as is the Committee's later statement that private providers should be prohibited from denying access to affordable and adequate services, treatments or information. ${ }^{155}$

\footnotetext{
${ }^{151} I d$. para. 18 .

${ }^{152}$ Id. para. 22.

${ }^{153}$ Id. para. 19.

${ }^{154} \mathrm{Id}$. (footnotes omitted).

${ }^{155}$ Id. para. 21.
} 
Consistently with its earlier practice, the Committee makes clear that the obligation to protect is the key one from a privatization perspective (and indeed in the context of ESR and business activities more generally) ${ }^{156}$ by including a statement in the "obligation to protect" section of the General Comment referring to privatization, stating that

[t]he increased role and impact of private actors in traditionally public sectors, such as in the health or education sectors, pose new challenges for States Parties in complying with their obligations under the Covenant. Privatization is not per se prohibited by the Covenant even in areas such as the provision of water or electricity, education or healthcare where the role of the public sector has traditionally been strong. Private providers however should be subject to strict regulations, imposing on them so-called "public service obligations": in the provision of water or electricity, this may include requirements concerning universality of coverage and the continuity of the service, pricing policies, quality requirements, and user participation. ${ }^{157}$

In outlining the challenges that the increased role and impact of private actors in what used to be predominantly public sectors poses for states parties in complying with their obligations under the Covenant, the Committee highlighted its concern that "goods and services that are necessary for the enjoyment of basic economic, social and cultural rights may become less affordable as a result of such goods and services being provided by the private sector, or that quality may be sacrificed for the sake of increasing profits." ${ }^{\prime 158}$ It emphasized that the provision by private actors of goods and services essential for the enjoyment of Covenant rights should not lead to the enjoyment of Covenant rights being made conditional on the ability to pay, thus creating new forms of socio-economic segregation, and that, given that privatization of the delivery of goods or services essential to the enjoyment of Covenant rights may result in a lack of accountability, "measures should be adopted to ensure the right of individuals to participate in assessing the adequacy of the provision of such goods and services." ${ }^{159}$ Here again though we can see that despite their framing as part of the right to protect, these challenges and the required state responses to them have a direct bearing on the obligation to fulfill ESR.

\footnotetext{
${ }^{156} I d$. para. 10.

${ }^{157}$ Id. para. 21 (footnotes omitted).

${ }^{158} I d$. para. 22.

${ }^{159} \mathrm{Id}$.
} 
In outlining examples of violations of the obligation to protect, the Committee highlighted several privatization-related ones, including a failure to incorporate a requirement linked to reasonable accommodation of persons with disabilities in public contracts and the exemption of certain projects or certain geographical areas from the application of laws that protect Covenant rights. ${ }^{160}$ It also raised the implications of state failure to regulate the real estate market and the financial actors operating on this market "so as to ensure access to affordable and adequate housing for all." ${ }^{, 161}$ Once more it is quite possible, indeed perhaps even more plausible, to consider these as measures inherent in the obligation to fulfill in situations in which it is future, expanded enjoyment rather than existing enjoyment of rights that is at issue.

The Committee's apparent ongoing intention that the obligation to protect do all the heavy lifting on privatization is also evidenced by the fact that the section of the General Comment on remedies opens with the statement that "[i]n discharging their duty to protect, States Parties should both create appropriate regulatory and policy frameworks and enforce such frameworks." 162 There is, however, no reason to suggest that state obligations with regard to remedies emanate solely from that level of obligation.

It is important to note that the duty to fulfill is not entirely missing. In a section devoted to it, the Committee says that the state "may require seeking business cooperation and support to implement the Covenant rights and comply with other human rights standards and principles"-while privatization is not mentioned by name, it clearly comes within the understanding of "cooperation and support." 163 And, in a move that is very welcome in terms of the criticisms made in this article, the Committee flags that the obligation to fulfill "also requires directing the efforts of business entities towards the fulfillment of Covenant rights. ${ }^{~ 164}$ However, this point, which signifies a potentially important development in terms of the Committee's engagement with privatization beyond the obligation to protect, is explored no further; as a result, the potential of the obligation to fulfill with regard to privatization goes unrealized.

Ultimately, therefore, the General Comment is a missed chance for the Committee to engage with the issue of privatization in a holistic way, teasing it out as an issue in light of the three elements of the typology, rather than trying to place different rights-troubling

\footnotetext{
${ }^{160} I d$.

${ }^{161} I d$.

${ }^{162} I d$. para. 38.

${ }^{163}$ Id. para. 23.

${ }^{164}$ Id. para. 24.
} 
elements of privatization under the different typology headings - an exercise that will inevitably be artificial given the overlap between actions required in terms of the different levels of obligation and the fact that privatization may have implications for all three. The obligations to respect and fulfill also have implications for how the state engages with, enables, supervises, regulates, and punishes rights-harming violators and processes. This needs to be recognized if the full obligation-related implications of privatization are to be addressed. By adopting a largely "business as usual" approach, the Committee perpetuates its inadequate conceptualization of privatization, state (in)action, and the scope of state obligations. It also appears to involve an unnecessary reconceptualization of the obligation to protect in order to address an issue that the obligation to fulfill could already deal with, thereby straining the former while stripping the latter of key meaning in the privatization context.

There is, however, a significant novel element of the Committee's work that raises a "new frontier" in terms of capturing privatization-caused rights harm with regard to ESR from a state-centric perspective, which must be considered here. This is the potential designation of a rights-harming nonstate actor as an "organ of state" on the basis that it is "acting on the instructions of, or under the direction or control of, [the] State in carrying out the conduct [in question]," thereby resulting in its actions being considered actions of state for which the relevant state is directly liable. ${ }^{165}$ In highlighting the possibility of state direct liability in those circumstances, the Committee specifically referred to this arising "in the context of public contracts." The Committee also referred to the possibility of direct liability “when a business entity is empowered under the State Party's legislation to exercise elements of governmental authority." 166 While this is an exciting innovation in terms of ESR law, ${ }^{167}$ and certainly holds potential for the human rights law "capture" of nonstate actors in a privatization context that satisfy these requirements, such an approach arguably raises more questions than it answers: in what circumstances would the Committee deem the degree of state direction or control sufficiently extensive to result in the organ of state designation?

\footnotetext{
165 Int'l Law Comm'n, Articles on Responsibility of States for Internationally Wrongful Acts, with Commentaries, art. 8, UN Doc. A/56/10 (2010), cited in CESCR GC No. 24, supra note 1, para. 11.

${ }^{166}$ CESCR GC No. 24, supra note 1, para. 11 (citing Articles on Responsibility of States for Internationally Wrongful Acts, supra note 165, art. 5).

${ }^{167}$ Indeed, it is also novel from the perspective of the Articles; for instance, the original Commentaries on Articles 5 and 8 did not make any mention any ESR-related examples. See JAMES CRAWFORD, THE INTERNATIONAL LAW COMMISSION'S ARTICLES ON STATE RESPONSIBILITY: INTRODUCTION, TEXT AND COMMENTARIES 100-102, 110-113 (2002).
} 
How will "governmental authority" be defined? ${ }^{168}$ These are highly disputed areas in the areas of IHRL in which these doctrines are already deployed. ${ }^{169}$ Similar constitutional law doctrines on the designation of nonstate actors as "organs of state" or "public authorities" for the purposes of the exercise of ESR-related obligations have been extensively analyzed in the context of domestic constitutional law jurisprudence and scholarship. ${ }^{170}$ There is enormous debate in relation to when and how such liability arises and limited examples of such being held to arise in practice. ${ }^{171}$ Given the Committee's failure to engage with privatization meaningfully thus far in its Concluding Observations, as well as its necessarily limited capacity given the other demands on its time, there is inevitably concern about how soon these questions will be answered.

Admittedly, it is open to question whether an inevitably limited treatment of a phenomenon as global and complex as privatization in a section of a broader General Comment could serve to "cure" the CESCR's inadequate approach to that phenomenon so far. It is a shame, however, that while the General Comment No. 24 undoubtedly expands upon the Committee's previous treatment of privatization, it arguably does so by "reinventing the wheel" of the obligation to protect and without the in-depth analysis of the different stages or loci of decision-making and forms of state action/inaction that a comprehensive treatment of privatization and ESR would entail. Overall, it is a pity to see an added layer of complexity in terms of the Committee's work in the form of its incorporation of the organ of state/governmental accountability doctrines when key questions about the relationship between privatization and its existing, well-established frameworks of obligation such as the tripartite typology remain outstanding. This is particularly so given the influence of the

\footnotetext{
${ }^{168}$ The other circumstance identified by the Committee for direct attribution of responsibility to the state- "if the circumstances call for such exercise of government functions in the absence or default of the official authorities" (CESCR GC No. 24, supra note 1, para. 11)-will not be dealt with as such a situation would not fall under the definition of privatization for the purposes of this article.

${ }^{169}$ See, for example, the discussion of the operation of Article 8 in the context of private security actors in Nigel D. White, Due Diligence Obligations of Conduct: Developing a Responsibility Regime for PMSCs, 31 CRIM. JUST. ETHICS 233 (2012).

${ }^{170}$ For examples of discussion of these doctrines, see TSVI KAHANA \& ANAT SCOLNICOV, BoundARIES OF State, Boundaries of Rights: Human Rights, Private Actors, and Positive Obligations (2016); Stu Woolman, Application, in Constitutional Law of South AFriCA, ch. 31 (Stu Woolman \& Michael Bishop eds., 2d ed. 2007, updated as of 2013).

${ }^{171}$ For two such examples in the South African and UK context, see AllPay Consolidated Investment Holdings (Pty) Ltd v. Chief Executive Officer, South African Social Security Agency 2014 (4) SA 179 (CC) paras. 52-60 (focused on the obligations of "organs of state" as defined in Section 239 of the South African Constitution in terms of a private company's constitutional obligations in the context of a public contract aimed at delivering the right to have access to social security, including social assistance, under Section 27(1)); R (Weaver) v. London and Housing Quadrant Trust [2009] EWCA (Civ) 587, [2009] 1 All ER 17 (holding that a registered social landlord regulated by Housing Corp is a "public authority," certain of whose functions "are functions of a public nature," for the purposes of Article 6 of the Human Rights Act 1998).
} 
Committee on the ESR and privatization work of the other international human rights bodies with an ESR mandate. In light of past practice, there is a significant risk that those bodies that have a significantly less evolved approach to privatization and ESR - i.e., the Committee on the Elimination of All Forms of Racial Discrimination, the CEDAW, the Committee on Migrant Workers, and the Committee on the Rights of Persons with Disabilities—will follow it uncritically, thereby rendering their work on privatization less coherent and more questionbegging. There may be a natural temptation to expand the reach of what constitutes state action as a way of dodging the challenge posed for human rights by privatization, but it is a route that should be embarked upon only with great care.

\section{CONCLUSION}

It was made clear at the outset of this article that privatization is neither inevitably in violation of, nor in compliance with, the international ESR framework. However, there is no doubt that privatization as currently implemented in a human rights system where states remain the principal actors poses major human rights concerns. De Feyter and Gómez Isa state that "from a legal perspective, the vulnerability to violations always increases as a consequence of a decision to privatise, because human rights law has so far insufficiently developed to respond to a situation in which private actors take over responsibility for

providing services essential to human rights." "While the reference to "always" is possibly an overstatement, the human rights system currently unquestionably fails to engage private actors adequately and hold them accountable in a meaningful way for their negative impacts on human rights in the context of privatization. This is at least partially due to the nonengagement of the key monitoring bodies of that system with the forms, processes, outputs, outcomes, and rights impacts of privatization in terms of the tripartite typology. As is clear from what has been said above, this is not simply attributable to the oft-cited and generally acknowledged shortcomings in the enforcement of international human rights standards generally; rather, it is also due to the failure thus far on the part of scholars, advocates and UN treaty-monitoring bodies to do the normative work necessary to render the prevailing IHRL framework - including the tripartite typology - as focused and effective as possible in terms of the theory and practice of privatization. This article deals with only some kinds of state (in)action that have been described as privatization and it has addressed only one

${ }^{172}$ De Feyter \& Gómez Isa, supra note 84 , at 8. 
element of the international ESR framework in detail. It is clear, however, that although the ESR framework as it stands has major shortcomings, there is enough there - and a lack of any meaningful IHRL alternative at the moment - to justify a much stronger engagement with the conceptual challenges posed to it by privatization. 